\title{
Om Sikringsanstalten i Nykøbing Sjælland og dens klientel
}

En opgørelse omfattende samtlige 203 forvarede patienter

fra åbningen i 1918 til 1. maj 1962.

Af

IVAN DANVAD, ERIK ANDERSEN og AAGE KIRKEGAARD

Fra Statshospitalet i Nyk $\phi$ bing Sjælland

(Chefer: Otto Jacobsen og Aage Kirkegaard).

\section{Indledning og formål.}

Medens de fleste kriminelle sindssyge d $\varnothing$ mmes til anbringelse i statshospitalerne for sindslidende, d $\varnothing$ mmes de særligt farlige sindssyge - mordere, voldsmænd, brandstiftere o. lign. - her i landet ofte til forvaring i Sikringsanstalten i Nyk $\phi$ bing Sjælland, der er den eneste eksisterende institution til dette formål i Danmark. Når behandlingen er så vidt fremskreden, at den uden større risiko kan fortsætte i et almindeligt hospital for sindslidende, s $\varnothing$ ges patienten overflyttet hertil, og fortsætter bedringen, vil patienten efterhånden få flere og flere friheder for til sidst at kunne udskrives helt.

Et væsentligt moment i hele denne procedure er bed $\phi$ mmelsen af risikoen for nye farlige handlinger på forskellige tidspunkter, resp. forskellige faser i sindslidelsens forl $\varnothing \mathbf{b}$. Sådan bed $\varnothing \mathrm{mmelse}$ er altid vanskelig, og hvor det drejer sig om patienter, der har vist sig meget farlige, kan et fejlsk $\phi$ n blive skæbnesvangert og i værste fald koste menneskeliv.

Ingen unders $\varnothing$ gelse, der kan bidrage til at kaste lys over denne risiko, bør derfor lades ugjort. Man har ment det af betydning at få en n $\varnothing$ jere analyse af det klientel, der gennem årene er udskrevet fra Sikringsanstalten, ikke blot for at opnå en klinisk og kriminologisk beskrivelse af dette, men også for at få en vurdering af prognosen bed $\varnothing \mathrm{mt}$ dels ved patienternes sociale karriere efter udskrivningen fra Sikringsanstalten, dels ved en undersøgelse over frekvensen af kriminelle recidiver, specielt til nye farlige handlinger. Endelig søges - i den udstrækning materialet gør det muligt - de sociale og karakterologiske forholds betydning for den farlige handling belyst, ligesom man har unders $\varnothing$ gt, om der er sammenhæng mellem sygdommens udbrud, dens forl $\varnothing \mathrm{b}$ og den farlige handlings art. 


\section{Hoad er Sikringsanstalten?}

„Den til Statshospitalet i Nyk $\varnothing$ bing Sjælland knyttede Sikringsanstalt", som dens officielle navn lyder, er en anstalt for særligt farlige sindssyge, oprettet efter anbefaling af Medicinalkommissionens betænkning af 1910 angående ordningen af sindssygeplejen i Danmark.

I henhold til denne vedtog rigsdagen den 29. april 1913 lov nr. $123 \mathrm{om}$ opf $\phi$ relse af et sindssygehospital og en dertil knyttet sikringsanstalt på Sjælland. Det hedder i lovens $\S 3$ : „I forbindelse med hospitalet, men som særskilt anstalt oprettes en sikringsanstalt til optagelse af personer, om hvem det $\mathrm{i}$ anledning af begåede lovovertrædelser enten ved dom eller ved administrativ resolution bestemmes, at der bør træffes sikkerhedsforanstaltninger overfor dem, dog at der i anstalten kun optages personer, som af justitsministeriet $\mathrm{i}$ overensstemmelse med indhentede erklæringer fra sundhedsstyrelsen sk $\phi$ nnes egnet til at optages i denne.“ De nærmere bestemmelser om anstaltens drift og virkemåde fastsættes ved regulativ.

If $\varnothing$ lge det nugældende regulativ (nr. 173 af 28. maj 1932) drives Sikringsanstalten i forbindelse med Sindssygehospitalet (nu: Statshospitalet) i Nyk $\phi$ bing under samme ledelse og med delvis samme personale og står under indenrigsministeriet, direkt $\varnothing$ ren for statshospitalerne. Regulativets $\S 2$ omtaler hvilke personer, der skal optages: „Anstalten er bestemt til optagelse af sindssyge mænd, om hvem det $\mathrm{i}$ anledning af begåede lovovertrædelser enten ved dom eller ved administrativ resolution bestemmes, at der b $\phi \mathbf{r}$ træffes sikkerhedsforanstaltninger overfor dem. Der optages dog kun personer, som af justitsministeriet i overensstemmelse med indhentet erklæring fra sundhedsstyrelsen sk $\varnothing$ nnes egnede dertil“".

\section{Sikringsanstaltens indretning, belægning og personale:}

Da anstalten f $\varnothing$ rst og fremmest skulle yde fængselsmæssig sikkerhed og derefter byde på behandlingsmæssige faciliteter, blev den i sin struktur stærkt fængselsmæssigt præget med mange isolationsceller, terrazzogulve, store kraftige dørlåse ind til de enkelte sengestuer og et meget strengt reglement, der ikke tillod nogen væsentlig individuel behandling. Den bestod af to fra hinanden isolerede bygninger, der hver husede 2 patientafdelinger. Der var kun ringe mulighed for beskæftigelsesterapi, og rundt omkring den lå tre haver omgærdet med høje mure.

Anstalten var oprindeligt beregnet til 50 patienter, og plejerstaben udgjorde 37 med en overplejer i spidsen. Administration og lægestab var fælles med Statshospitalet. De f $\varnothing$ rste 5 patienter modtoges den 18. juli 1918, og i løbet af de følgende år steg an- 
tallet jævnt og sikkert, så det i 30 -erne og 40 -erne ofte var i nærheden af eller på maksimumantallet 50 .

Fire forhold har i tidens $1 \varnothing \mathbf{b}$ haft betydning for Sikringsanstaltens belægning: 1) Åbningen af sikringsafdelingen for åndssvage i Rødbygård 1930, hvorefter de farlige åndssvage anbragtes der. 2) Åbningen af forvaringsanstalten i Herstedvester i 1935, hvorved antallet af psykopater mindskedes. 3) Indfǿrelse af de moderne behandlingsmetoder, specielt med psykofarmaka, i midten af 50 -erne. 4) Moderniseringen af institutionen i 1956 og navnlig i 1961-62, hvorved der indrettedes hyggeligere forhold, gode opholdsstuer med radio, fjernsyn etc., hvilket i forbindelse med udvidelse af lægestaben bedrede muligheden for individuel behandling.

Medens de f $\varnothing$ rste forhold kun satte sig spor i sammensætningen af Sikringsanstaltens klientel, havde de to sidste, navnlig indførelsen af psykofarmaka, afg $\phi$ rende betydning for st $\varnothing$ rrelsen af Sikringsanstaltens belægning.

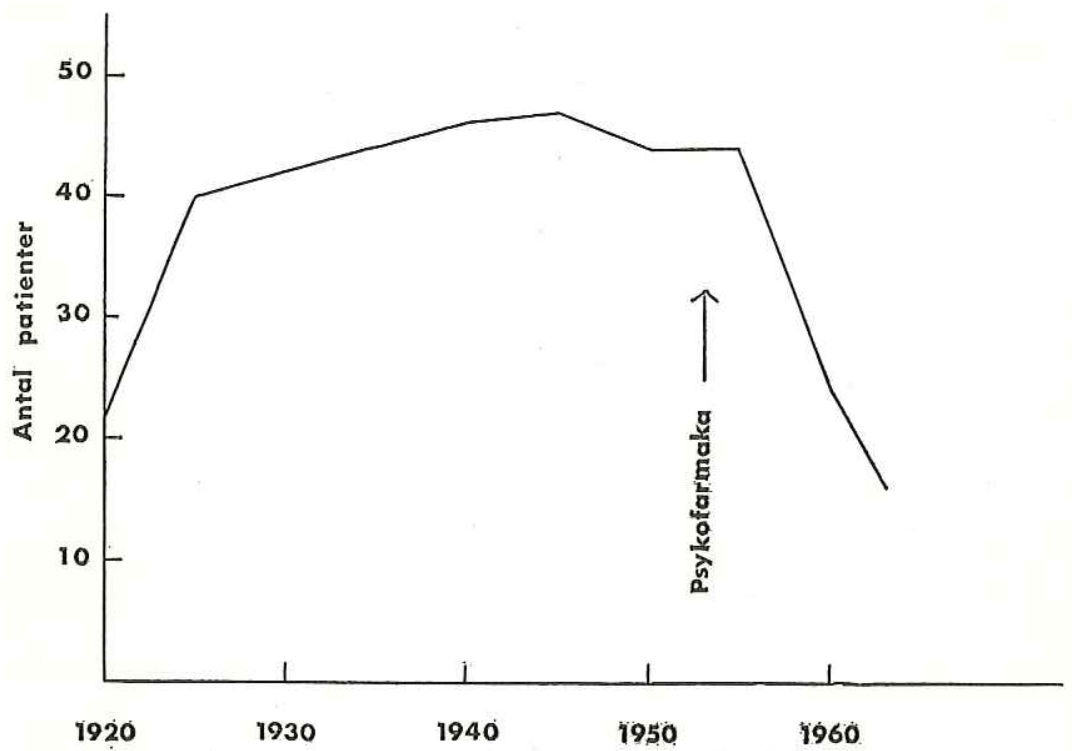

Fig. 1. Patientbelægningen på SA 1920-1963.

Takket være en stærk nedgang i patientantallet og den pacificerende indflydelse af de nyere behandlingsmetoder, har man været i stand til at modernisere Sikringsanstalten, hvilket har haft meget stor betydning for patienterne. 
Den nuværende Sikringsanstalt har plads til 17 patienter uden overbelægning. Da det af terapeutiske grunde anses for n $\varnothing$ dvendigt at have mindst 2 afdelinger at rokere imellem, er personalet forholdsvis stort, i alt 27 mand. I sin nye skikkelse rummer anstalten udelukkende 1- og 2-sengsstuer; der er et stort værksted, hvor som regel $10-12$ patienter er beskæftiget, en stor fælles have, samt en lille have beregnet for patienter, der enten sætter pris på at være alene, eller som af sikkerhedsgrunde b $\phi \mathrm{r}$ være det. Det meget strenge reglement har kunnet lempes lidt efter lidt, så der nu er en husorden, der ikke er strengere, end at man til enhver tid kan individualisere efter den enkelte patients behov.

\section{Patientmateriale og metodik.}

Udgangsmaterialet udg $\phi$ res af alle de 204 patienter, som har været indlagt til forvaring på Sikringsanstalten, det være sig ved dom eller ved justitsministerielle resolutioner, fra åbningen i 1918 indtil skæringsdagen for unders $\varnothing$ gelsen, 1. maj 1962. Herfra går en frihedskæmper, som af specielle grunde var indlagt af frihedsrådet $\mathrm{i}$ besættelsens sidste dage. Materialet omfatter således i alt 203 patienter, der alle er mænd.

Nærværende arbejde omfatter en opg $\varnothing$ relse og en efterunders $\varnothing$ gelse. Opg $\phi$ relsen er foretaget på grundlag af eksisterende journaler, mentalobservationserklæringer og andre aktstykker til og med patienternes indlæggelse i Sikringsanstalten. Efterunders $\varnothing$ gelsen er foretaget på grundlag af oplysninger om patienternes forhold efter udskrivningen fra Sikringsanstalten indhentede fra andre psykiatriske institutioner, forvaringsanstalter og fængsler. Patienter, der har levet udenfor institutioner, har man fået oplysning om fra rigsregistraturen, som velvilligt har stillet sine oplysninger om patienterne til rådighed for unders $\phi$ gelsen.

En personlig efterunders $\varnothing$ gelse er ikke foretaget dels af tidsmæssige grunde, dels af diskretionshensyn. For langt de fleste patienters vedkommende har man fået de $\phi$ nskede oplysninger om deres færden indtil unders $\varnothing$ gelsestidspunktet eller patienternes d $\varnothing$ d. 8 patienters skæbne efter udskrivningen har man ikke kunnet efterspore.

Ved enkelte problemstillinger er materialet opdelt i 4 grupper ( A, B , C og D) efter løbenumre med henblik på tidsfaktorens indflydelse. Da man $\phi$ nskede at gøre grupperne lige store, blev gruppe A: $1918-24$, gruppe B: $1924-32$, gruppe C: $1932-43$ og gruppe D: tiden fra 1943.

Hvor statistisk beregning er anvendt, er det altid en $\mathrm{X}^{2}$-analyse, som denne er beskrevet hos Kemp (1955). 


\section{Opgфrelsen.}

Diagnoser:

I denne opgørelse har man anvendt den for tidspunktet for indlæggelsen i Sikringsanstalten gældende diagnose, idet gennemgangen af senere indhentede oplysninger ikke har ændret den diagnostiske fordeling væsentligt. Man har undersøgt det samlede patientmateriales diagnostiske fordeling og suppleret dette med 6 tværsnitsundersøgelser fra 1938-1962.

Som det fremgår af tabel 1, udgøres den største gruppe af de skizofrene $(45 \%)$, den næstst $\varnothing$ rste er psykopaterne $(29 \%)$, medens ingen af de $\phi$ vrige grupper når over $10 \%$. Nærmest kommer epileptisk sindssygdom med $9 \%$, hvorefter følger psykogen psykose med $6 \%$ og oligofreni med $5 \%$ af materialet. Af de resterende $6 \%$ er halvdelen tilfælde, hvor man ikke med rimelig sikkerhed har kunnet rubricere patientens psykose i det gældende diagnosesystem.

Tabel 1. Patienternes fordeling efter hoveddiagnoser.

$\left.\begin{array}{lrr}\hline & \text { ptt. } & \% \\ \hline \text { Skizofreni } & 91 & 45 \\ \text { Psykopati } & 58 & 29 \\ \text { Epilepsi } & 19 & 9 \\ \text { Psykogen psykose } & 12 & 6 \\ \text { Oligofreni } & 11 & 5 \\ \text { Manio-depressiv psykose } & 2 \\ \text { Alkoholisk demens } & 2 \\ \text { Encephalitis chron. } & 1 \\ \text { Dementia paralytica } & 1 \\ \text { Usikre tilfælde } & 6\end{array}\right)$

Sammenligner man disse tal med resultatet af forskellige tværsnitsunders $\varnothing$ gelser fra Sikringsanstalten fra 1938 (Lemmergaard \& Ravn, 1938), 1946 (Otto Jacobsen, 1947), 1953 og 1956 (Aage Kirkegaard, 1956), samt med ikke tidligere offentliggjorte tværsnitsunders $\varnothing$ gelser fra 1957 og 1962 ses (tabel 2), at skizofrenien er endnu mere dominerende og psykopatien betydelig mindre repræsenteret i tværsnittene end i hele materialet.

Medens således skizofrenien er den stærkest repræsenterede psykose, er det et spørgsmål, om denne sygdom også er stærkere repræsenteret på Sikringsanstalten end på de psykiatriske hospitaler som helhed. 
Tabel 2. Patientfordelingen på Sikringsanstalten.

(Tværsnit 1938, 1946, 1953, 1956, 1957 og 1962).

\begin{tabular}{lrrrrrr}
\hline & 1938 & 1946 & 1953 & 1956 & 1957 & 1962 \\
\hline Skizofreni & 32 & 30 & 30 & 25 & 16 & 12 \\
Epilepsi & 2 & 5 & 5 & 4 & 3 & 2 \\
Psykogen psykose & 1 & 4 & 4 & 1 & 1 & 0 \\
Psykopati & 11 & 7 & 4 & 3 & 2 & 5 \\
Organiske psykoser & 1 & 0 & 2 & 2 & 2 & 2 \\
\hline I alt & 47 & 46 & 45 & 35 & 24 & 21
\end{tabular}

Til belysning heraf har man sammenlignet tværsnit på Sikringsanstalten med tværsnit på samtlige psykiatriske hospitaler i Danmark 26.9.1957 og 2.10.1962 (Arrentsen \& Strömgren, 1959; Juel-Nielsen \& Strömgren, 1963) suppleret med oplysninger fra Kolonien Filadelfia's epileptikerafdeling og psykopatforvaringsanstalterne. Af den på dette grundlag udarbejdede tabel 3 fremgår følgende:

Tabel 3. Den procentvise fordeling af patienterne på Sikringsanstalten og i baggrundsmaterialerne 1957 og 1962 (jvf. teksten).

\begin{tabular}{lrrrrr}
\hline & \multicolumn{2}{c}{1957} & \multicolumn{2}{c}{1962} \\
& SA-\% & total-\% & SA-\% & total-\% \\
\hline Skizofreni & 67 & $52.2(68)$ & 57 & $47.4(68)$ \\
Epilepsi & 13 & $7.5(9)$ & 9.5 & $7.1(13)$ \\
Psykogene psykoser & 4 & 2.8 & 0 & 3.4 \\
Psykopati & 8 & $11.7(15)$ & 24 & $9.0(12)$ \\
Organiske psykoser & 8 & 2.4 & 9.5 & 2.8 \\
Andre & 0 & 23.4 & 0 & 30.3 \\
\hline I alt & 100 & 100.0 & 100.0 & 100.0
\end{tabular}

Visse grupper er som ventet ikke repræsenteret i Sikringsanstalten. Dette gælder alle ikke-psykotiske patienter, som efter regulativet ikke skal modtages. En undtagelse herfra er i praksis psykopaterne. Disse patienter er på gerningstidspunktet eller senere i fængsel eller forvaringsanstalt blevet episodisk psykotiske eller kommet $\mathrm{i}$ en tilstand, der må sidestilles med psykose. De præsenile og senile psykoser er naturligvis ikke repræsenteret. De patienter, der således ikke er repræsenteret på Sikringsanstalten, er for oversigtens skyld slået sammen i gruppen ,andre“.

I 1957 fandtes $14 \%$ flere og i $19629 \frac{1}{2} \%$ flere skizofrene i Sikringsanstalten end i baggrundsmaterialet. Dette skyldes imid- 
lertid, at patienter i gruppen ,andre“ ikke er repræsenteret i Sikringsanstalten. Korrigerer man herfor ved at fradrage gruppen ",andre" i baggrundsmaterialet ses, at de skizofrene patienter da udg $\phi \mathrm{r}$ samme procentdel af baggrundsmaterialet i 1957 og 1962, nemlig i begge tilfælde $68 \%$ (tabel 3, tallene i parentes).

I 1957 fandtes altså samme procentdel skizofrene patienter i Sikringsanstalten, som i det „reducerede“ baggrundsmateriale. I 1962 var der derimod $11 \%$ færre skizofrene i Sikringsanstalten end i det „reducerede“ baggrundsmateriale, hvilket tyder på, at de skizofrene patienter ikke i så h $\varnothing$ j grad indlægges i Sikringsanstalten mere eller hurtigere udskrives derfra igen.

Tabel 4. De forskellige diagnosers repræsentation på Sikringsanstalten og blandt mænd i samtlige hospitaler ved tværsnitunders $\varnothing$ gelserne i 1957 og 1962 (se teksten).

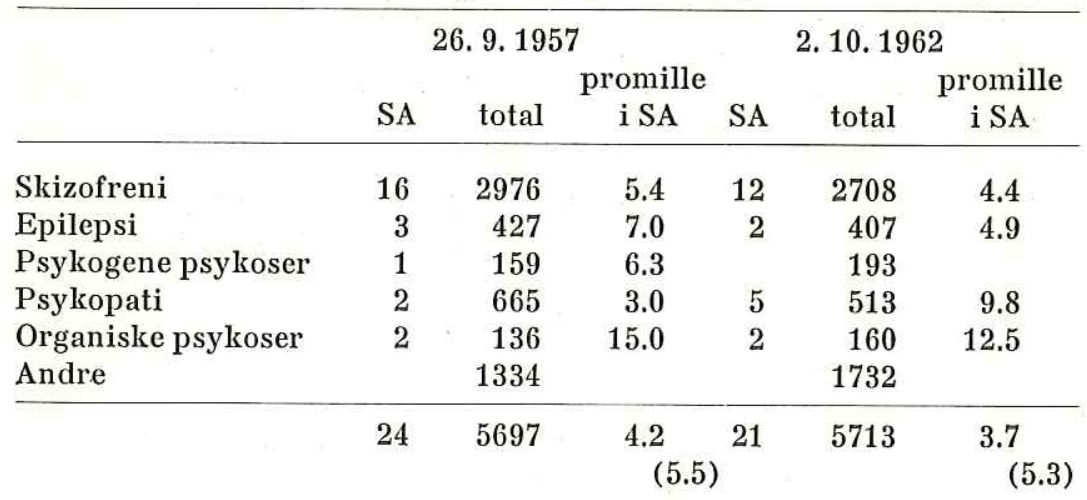

Dette bekræftes yderligere af tabel 4, der viser, hvor mange promille af samtlige indlagte patienter med en given diagnose, der på samme tidspunkt lå i Sikringsanstalten.

For samtlige diagnoser drejer det sig om 4,2 promille og 3,7 promille i hhv. 1957 og 1962, men fradrager man i baggrundsmaterialet gruppen ,andre“ på samme vis som ovenfor fås hhv. 5,5 og 5,3 promille, altså ingen væsentlig ændring. Derimod er Sikringsanstaltens andel i de skizofrene patienter og iøvrigt også i epileptikerne tilsyneladende faldet fra 1957 til 1962.

\section{De farlige handlinger:}

De farlige handlinger, der har betinget patienternes indlæggelse i Sikringsanstalten, fremgår af tabel 5.

Den st $\varnothing$ rste gruppe udg $\varnothing$ res af 101 patienter, der har gjort sig skyldige i grove voldshandlinger af farlig karakter. Det drejer 
sig om grov vold (44 patienter) og røveri (6 patienter) samt stærk korporlig aggressivitet $\mathrm{i}$ forskellige institutioner (51 patienter), især i psykiatriske hospitalsafdelinger.

Tabel 5. Patienterne fordelt efter diagnoser og de farlige handlingers art.

\begin{tabular}{lrrrrrrrr}
\hline & $\begin{array}{c}\text { skizo- } \\
\text { freni }\end{array}$ & $\begin{array}{c}\text { psyko- } \\
\text { pati }\end{array}$ & $\begin{array}{r}\text { epi- } \\
\text { lepsi }\end{array}$ & $\begin{array}{c}\text { psykogen } \\
\text { psykose }\end{array}$ & $\begin{array}{c}\text { oligo- } \\
\text { freni }\end{array}$ & andre total & $\%$ \\
\hline Grove voldshandlinger & 61 & 15 & 13 & 3 & 6 & 3 & 101 & $(50 \%)$ \\
Mord og mordfors $\varnothing \mathrm{g}$ & 15 & 16 & 3 & 3 & 2 & 5 & 44 & $(22 \%)$ \\
Brandstiftelse & 8 & 12 & 2 & 1 & 4 & 2 & 29 & $(14 \%)$ \\
Voldtægt & 3 & 8 & 0 & 0 & 2 & 0 & 13 & $(6 \%)$ \\
Grove trusler alene & 3 & 8 & 1 & 3 & 0 & 0 & 15 & $(7 \%)$ \\
Andet & 4 & 6 & 0 & 2 & 0 & 2 & 14 & $(7 \%)$ \\
\hline I alt & 94 & 65 & 19 & 12 & 14 & 12 & 216 & \\
Flere farlige handlinger & 3 & 7 & 0 & 0 & 3 & 0 & 13 & $(6 \%)$ \\
\hline Patienter i alt & 91 & 58 & 19 & 12 & 11 & 12 & 203 &
\end{tabular}

Disse 101 patienter udg $\phi \mathbf{r}$ halvdelen af det samlede patientmateriale. Det ses, at de fleste er skizofrene. $2 / 3$ af samtlige skizofrene patienter findes $\mathrm{i}$ denne gruppe, og grove voldshandlinger er således de skizofrenes største enkeltgruppe, hvorved de skizofrene afviger signifikant fra de $\phi$ vrige patienter $(p<0,001)$.

Illustrerende er følgende sygehistorie:

Sygehistorie S.A. nr. 41:

Patienten var $s \varnothing n$ af et postbud og dennes hustru, nr. 5 af 8 søskende. Faderen var fordrukken, og forældrene blev skilt, da han var $4-5$ år gammel. I skolen var han ustadig, doven, urolig og skulkende. Senere havde han aldrig haft fast arbejde, men ernærede sig ved tilfældigt forefaldende jobs. Han misbrugte tidligt spiritus og var under påvirkning heraf opfarende og provokerende. Fra 17 til 33 års alderen var han straffet $\mathrm{i}$ alt 37 gange, hovedsageligt for vold mod sagesl $\varnothing$ se personer, bl. a. moderen, gadeuorden o.l. I alt havde han siddet $\mathrm{i}$ fængsel i 6-7 år. Ved en mentalobservation 20 år gammel betegnedes han som et degenereret individ med mangelfuld åndelig udvikling såvel i intellektuel som i moralsk henseende, og man fandt, at han under alkoholpåvirkning utvivlsomt let bragtes ud af en i forvejen meget ustadig ligevægt.

Han blev efterhånden en rædsel for sin hjemby, hvor man bl. a. så sig n $\varnothing$ dsaget til at indrette en speciel sikkerhedscelle med fast inventar til ham. 34 år gammel blev han mentalobserveret på statshospital, hvor han r $\phi$ bede paranoide ideer og storhedsforestillinger, var livligt associerende og vidtløftig. 
Året efter indlagdes han så i Sikringsanstalten. De første år var han en overordentlig vanskelig patient, som ofte var aggressiv og voldsom. Ind imellem var han dog gemytlig, groft spøgende og brovtende, og han havde desuden en række megalomane forestillinger, samt giftfrygt. Med årene blev han tiltagende vrøvlende på mere godmodig vis, nu kun sjældent korporlig aggressiv, men ofte opbrusende og udskældende. Denne udvikling fortsatte, han blev mere hypokondert præget, idelig optaget af sin afføring. Efterhånden betragtedes han som en hyggespreder, ganske uimodståelig i sin groteske humor.

Efter 34 års ophold i Sikringsanstalten fik patienten justitsministeriets tilladelse til en udflugt sammen med 3 plejere, og året efter tiltrådte myndighederne hans overflyttelse til Statshospitalet ved Århus. Her har han fortsat været meget paranoid, men dog klaret sig pænt og ikke på noget tidspunkt været korporligt aggressiv.

Diagnosen har både i Sikringsanstalten og på Statshospitalet ved Århus været schizophrenia paranoides.

Ligeledes findes der i gruppen relativt mange patienter med epileptiske sindssygdomme, nemlig 13 ud af i alt 19. Det er herved også epileptikernes største enkeltgruppe af farlige handlinger, omend disse patienter ikke adskiller sig signifikant fra de $\phi$ vrige $(0,10>p>0,05)$. 15 patienter var psykopater, og ca. $1 / 4$ af disse findes således også her.

Materialets næstst $\varnothing$ rste gruppe omfatter mord (30 patienter) og mordfors $\phi g$ (14 patienter), i alt 44 patienter (22\%). Heriblandt findes 16 psykopater, og gruppen er hermed disses største enkeltgruppe af farlige handlinger, men de adskiller sig ikke signifikant fra de $\phi$ vrige på dette punkt $(0,95>p>0,10)$. Der er 15 skizofrene i gruppen, der således er disses næstst $\varnothing$ rste enkeltgruppe $(0,95>\mathrm{p}>0,10)$.

Sygehistorie S.A. nr. 13:

29-årig mand, der i svær spirituspåvirket tilstand og muligvis en epileptisk tågetilstand dræber sine to plejeb $\phi r n$. Han var 10 år i Sikringsanstalten og da apsykotisk, uden epileptiske manifestationer, men til tider psykopatisk præget.

Faderen var en drikfældig landarbejder. Patienten gik i almindelig landsbyskole, var herefter i bagerlære, havde forskelligt arbejdsmandsarbejde og sejlede en tid. Han blev gift 20 år gammel, men 1 år efter fik han en datter med en 14-årig pige. Han og hustruen tog barnet til sig som plejebarn. De $\phi$ konomiske forhold var ret gode. Trods utroskab angav begge ægtefæller ægteskabet som tilfredsstillende. Patienten var altid meget barnagtig og pjanket, havde drukket tæt allerede som lærling, men ved giftermålet var han i „Good Templar“ og total afholdsmand i et halvt års tid, hvorefter han igen optog drikkeriet, og han kunne indtage $3 / 4-1$ liter brændevin daglig, uden at det kunne 
ses på ham. Han drak fortrinsvis i hjemmet. Fra 18-20 års alderen afsonede han flere fængselsstraffe for tyveri, gadeuorden og alfonseri. Han foretog den farlige handling som 26-årig, da han skar halsen over på de to mindreårige plejeb $\varnothing \mathrm{rn}$. Aftenen f $\varnothing \mathrm{r}$ havde han $\mathrm{k} \phi \mathrm{bt}$ en hel flaske brændevin og drak da halvdelen. På drabsdagen om morgenen gav han hustruen og børnene kaffe på sengen. I løbet af formiddagen drak han ca. $3 / 4$ flaske brændevin. Da hustruen senere forlod huset, virkede patienten ikke spirituspåvirket. Medens han var alene med børnene, foretog han drabene. Ved politiets ankomst så han sig forundret omkring og vaklede som en drukken. Foreholdt gerningen svarede han: „Ja, så er man af med dem“. I køkkenet fandt man en snor hængende i en krog fra loftet, idet det $\varnothing$ jensynligt havde været hans hensigt at hænge sig. Ved det første tilsyn i hjemmet af amtslægen fandtes han ikke at være sig bevidst, og han var ikke klar over, hvad der var foregået. Han indlagdes på sygehus, hvor han virkede svært beruset. Senere, efter flere timers $s \varnothing v n$, var han uklar og tildels selvmodsigende, uh $\varnothing$ visk i tale og gjorde fors $\emptyset \mathrm{g}$ på at være morsom. Efter atter at have sovet, vågnede han sent om aftenen fuldstændig rolig og samlet, men med massiv amnesi for dagens begivenheder. Han forstod ikke, hvorfor han var på hospital og nægtede at tro på forklaringer herom. Da sagens rette sammenhæng gik op for ham, brød han sammen og hulkede som et barn.

Han overflyttedes til psykiatrisk hospital, hvor han den følgende tid var normal i adfærd, uden epileptiske anfald, men betegnedes som „,et $i$ etisk og intellektuel henseende svagt begavet menneske uden åndelig selvstændighed og modstandskraft, men ikke sindssyg eller åndssvag “. I gerningsøjeblikket var han i ,en abnorm bevidsthedstilstand, som enten skyldtes beruselse eller et ubemærket epileptisk tilfælde eller en samvirken af begge dele“. Ifølge retslægerådet måtte patienten antages at lide af epilepsi og var forfalden til spiritus. Da han gerningsdagen og aftenen forud havde nydt rigeligt alkohol, var der overvejende sandsynlighed for, at der, da han begik de forbryderiske handlinger, havde været et sådant sindssygdomsanfald til stede, for hvilket han bagefter ingen erindring har haft.

Patienten opholdt sig herefter i 2 år i arrest, hvor han intet abnormt fremb $\varnothing$ d. Da man mente, at han ikke hørte hjemme hverken i sindssygehospitaler eller fængsler, indlagdes han ved justitsministeriel resolution i Sikringsanstalten, hvor han var i 10 år. Han frembød her intet psykotisk, havde ikke epileptiske anfald, men kunne til tider virke psykopatisk, uden at der dog var særlige vanskeligheder. Efter udskrivningen klarede han sig godt socialt, var ikke drikfældig og havde ikke kriminelle recidiver, ligesom han ikke havde frembudt tegn på sjælelige lidelser og ikke havde haft epilepsi. 
Sygehistorie S.A. nr. 93:

29-årig mand med posttraumatisk epilepsi, der med en sygeligt ringe motivering $\mathrm{i}$ en præparoxysmal irritationstilstand dræber en sagesl $\phi \mathrm{s}$ medpatient med et slag i hovedet.

Der var ingen kendte dispositioner til sinds- eller nervelidelser. Han havde været rask og upåfaldende, indtil han 25 år gammel faldt $10 \mathrm{~m}$ ned på beton og slog hovedet. Han var bevidstløs i et halvt døgn, og der var bl $\phi$ dning fra venstre $\phi$ regang. Siden dette traume havde han hyppige epileptiske anfald af grand mal type, men også ofte epileptiske tågetilstande, hvorunder han bl. a. gjorde fors $\emptyset \mathrm{g}$ på at springe ud gennem vinduer. Forud for sine anfald var han yderst affektpirrelig og dysforisk.

Han havde gået i almindelig kommuneskole og var derefter uddannet som skibsværftsarbejder.

Fra 26 års alderen indlagdes han flere gange på psykiatriske hospitaler, hvor han periodevis var rethaverisk, kværulerende og havde enkelte kortvarige tågetilstande forudgået af affektpirrelighed. 27 år gammel idømtes han fængselsstraf for et alvorligt overfald på en politibetjent, som han havde set sig gal på.

Under et hospitalsophold dræbte han 29 år gammel en sagesl $\phi s$ medpatient ved at tilf $\varnothing j$ e ham flere voldsomme slag $i$ hovedet med en stol. Overfaldet foregik i en præparoxystisk dysfori. Patienten, som ikke var uklar, havde følt sig generet, fordi medpatienten lå og udst $\varnothing$ dte sn $\varnothing$ ftelyde. 3 timer efter drabet fik patienten et typisk grand mal anfald.

Patienten overflyttedes herefter ved justitsministeriel resolution til Sikringsanstalten. De f $\varnothing$ rste år her var han meget urolig, støjende, voldsom og aggressiv, vredladen, iturivende og ofte groft urenlig og koprofag. Ind imellem forekom han forvirret og gav udtryk for forskellige vrangforestillinger, ligesom han virkede tiltagende dement. Han havde hyppige krampeanfald forudgået af en ekstraordinær affektlabilitet. Han blev i begyndelsen behandlet med phenemal og diemal, men senere med phenytoin og phenemal, uden at disse stoffer dog kunne holde ham anfaldsfri.

Fra 46 års alderen var den psykiske tilstand noget mere afdæmpet uden egentlige aggressive handlinger. Efter i flere år at have haft uforklarlige feberattakker, d $\varnothing$ de patienten efter nogen tids træthed og svimmelhed med hepato- og splenomegali, ascites, perifere $\phi$ demer og infiltrater i lungerne. Den følgende sektion gav ikke nogen sikker diagnose, men en systemsygdom ansås for mest sandsynlig.

Sygehistorie S.A. nr. 98:

41-årig mand, der overfaldt den person, han anså for at være hovedmanden $i$ en forf $\phi$ lgelse af ham. Han blev oprindeligt antaget for psykopat, men havde allerede på gerningstidspunktet paranoide forestillinger og viste sig efterhånden at være skizofren. 
Han var opvokset på landet som nr. 3 af 14 søskende, hvoraf de 3 d $\varnothing$ de tidligt af medf $\varnothing$ dte defekter. Hjemmet var præget af fattigdom, faderen var skomager og havde i sine unge år været en hidsig natur. Patienten blev 21 år gammel appendektomeret, som 28-årig havde han spansk syge kompliceret med otitis media. Fra 36 års alderen var han indlagt flere gange bl. a. til operation for lyskebrok og for ulcus ventriculi. Fra 40 års alderen fik han IP på grund af dyspepsi, som persisterede siden hen.

Han havde gået $\mathrm{i}$ almindelig landsbyskole, kom derefter i grovsmedelære, men måtte holde op efter et års forløb på grund af utilstrækkelig fysik. Han blev derefter udlært 20 år gammel som klejnsmed, hvorefter han de f $\varnothing$ lgende år ernærede sig ved faget. Fra 30 års alderen boede han hos forældrene på grund af svigtende helbred. Han var ikke gift eller forlovet. Fra 20 års alderen havde han været noget drikfældig.

Han var naturlig som barn, men allerede i sin læretid forekom han noget afvigende, betegnedes som sær, hidsig og opfarende, og under hospitalsindlæggelser var han en meget vanskelig patient, som overfusede personalet og flere steder blev udskrevet $\mathrm{i}$ utide på grund af

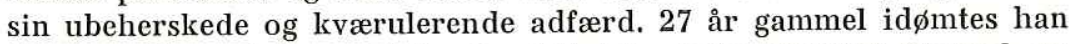
40 dages fængsel for vold imod politiet i spirituspåvirket tilstand, og i de f $\varnothing$ lgende år blev han mere og mere kværulerende og affektpræget. Han søgte ustandselig hjælp hos sygekasse og fors $\varnothing$ rgelsesvæsen og var overfor personalet visse steder meget ubehagelig, kværulerende og tidvis ligefrem truende.

Han foretog den farlige handling, da han var 41 år gammel. På gerningsdagen havde han om morgenen fået afslag på ansøgning om et legat, hvilket han opfattede som forfølgelse fra forskellig side. Han ops $\varnothing$ gte en installat $\varnothing \mathrm{r}$, som var medlem af hjælpekassen, og som patienten anså for at være hovedårsagen til afslaget. Efter et kort skænderi slog patienten pludselig installat $\varnothing$ ren i hovedet med en flaske, som indeholdt rå salpetersyre. Flasken gik itu, og installat $\varnothing$ ren fik svære ætsninger $\mathrm{i}$ hovedet og på halsen, hvilket senere medf $\varnothing$ rte hans d $\varnothing$ d. Efter overfaldet var pt. meget nedbøjet og meldte sig selv til politiet. Under arrestopholdet blev han psykotisk, urolig, hørelseshallucineret og desorienteret. Han blev 42 år gammel $\mathrm{d} \phi \mathrm{mt}$ til anbringelse i Sikringsanstalten, og her forværredes hans sindslidelse yderligere. Han var såvel hørelses- som synshallucineret, fremkom med paranoide ideer af efterhånden megaloman karakter, talte skruet med neologismer. Han var i mange år en meget farlig patient, som gentagne gange rettede pludselige og voldsomme angreb mod omgivelserne, men med årene faldt han mere til ro, og en tiltagende demens afblegede hans tidligere voldsomme adfærd. Han døde 57 år gammel efter nogen tids svagelighed, præget af dyspepsi og cardiale symptomer. 
Sygehistorie S.A. nr. 197:

33-årig paranoid, skizofren patient, der dræbte sin moder. Under det efterf $\varnothing$ lgende hospitalsophold virkede han truende, hvorfor han indlagdes i Sikringsanstalten.

Han var $s \varnothing \mathrm{n}$ af en lærer og ældst af to s $\varnothing$ skende. Efter studentereksamen og juridisk embedseksamen arbejdede han f $\varnothing$ rst $i$ et ministerium og senere som sagf $\varnothing$ rerfuldmægtig. Han var forkælet af moderen, noget krævende, dominerende, arrogant, men en yderst velbegavet jurist, udpræget teoretiker, men også praktisk dygtig, var videnskabeligt interesseret og udarbejdede en lærebog samt besvarede en prisopgave.

I forbindelse med besvarelsen af prisopgaven, der ikke blev præmieret, udviklede han en række paranoide symptomer, skrev splittede breve fyldt med storhedsforestillinger til forskellige juridiske professorer. Han led af forf $\varnothing$ lgelsesforestillinger, hvorunder han foretog et suicidalfors $\emptyset \mathrm{g}$, der medf $\phi$ rte hans indlæggelse i statshospital 31 år gammel under diagnosen: Psychosis paranoides, obs. for schizophrenia. Han behandledes med insulincoma og NCE, tilstanden var herunder noget svingende. Under et bes $\varnothing \mathrm{g}$ i byen sammen med moderen nægtede han at vende tilbage til hospitalet og blev derfor udskrevet. 14 dage senere strangulerede han moderen efter en pludselig indskydelse. Han overskar desuden hendes halspulsåre og forsøgte derefter at kastrere sig selv med et barberblad. Han blev nu genindlagt i statshospitalet, hvor han var autistisk præget og hallucineret på syn og h $\varnothing$ relse, havde tankemylder og påvirkningsfornemmelser. Han mente, at han under drabet på moderen havde været besat af Djævelen, og at drabet var en forudbestemmelse. Han gav ikke udtryk for anger over sin handling. Under hospitalsopholdet blev han tiltagende verbalt truende og vredagtig, rastl $\varnothing \mathrm{s}$ og urolig, knuste ruder, talte om gift i maden og var ind imellem opkørt. På grund af den truende adfærd overflyttedes han 33 år gammel til Sikringsanstalten. Han virkede her følelsesmæssigt afstumpet, var tydeligt paranoid og skruet. Under hele opholdet, hvor han behandledes medikamentelt, var den emotionelle kontakt dårlig, der var ingen reel emotionel reaktion, når drabet omtaltes. Han var altid meget afmålt, kontaktmæssigt udenfor rækkevidde, men ellers flink, efterrettelig, høflig og yderst korrekt. Fra Sikringsanstalten blev han overflyttet til et statshospital 34 år gammel. Der var han fortsat ind imellem vredagtig, mere katalont præget. Indtil opg $\phi$ relsestidspunktet har der ikke været voldsommere, aggressive handlinger.

Materialets trediest $\varnothing$ rste gruppe af farlige handlinger udg $\phi$ res af de 29 brandstiftere (14\%). 12 patienter var psykopater $(0,10>p>0,05), 8$ var skizofrene og 4 var oligofrene. 
Sygehistorie S.A. $\mathrm{nr}$. 82:

22-årig småt begavet og psykopatisk præget mand, der indlagdes på grund af alvorlige ildspåsættelser.

2 s $\varnothing$ skende var psykopatisk prægede. Han var f $\phi$ dt udenfor ægteskab, forældrene giftede sig få år efter hans f $\phi$ dsel. Han var fra sit sjette år på børnehjem, efter skolegangen en kort tid i gartnerlære, men blev afskediget. De følgende år 6-7 forskellige landbrugspladser, som han ofte forlod i utide.

Som barn var han lydig, flittig, ofte åndsfraværende og spekulativ. Ind imellem rapsede han, kunne ikke med lærekammeraterne og karakteriseredes af arbejdsgiverne vekslende som "god og tjenstvillig“ eller ,en underlig sær fyr". Fra 17-18 års alderen havde han dysforier og i forbindelse hermed hovedpine udgående fra venstre $\varnothing j e$, der var blindt efter traume $\mathrm{i}$ barndommen. I 18 års alderen id $\varnothing$ mtes han 120 dages fængsel for tyverier.

Fra sit 19. til sit 21. år satte han ild på 3 gårde. Ildspåsættelserne var alle udført i en dysforisk, irritabel tilstand, forårsaget af mindre forurettelser og modgang. Efter forudgående mentalobservation, der karakteriserede ham som dårligt begavet psykopat på infantilt udviklingstrin, indlagdes han i Sikringsanstalten 22 år gammel.

Her var han som oftest venlig, hjælpsom og nem, men med ret udtalte periodevise dysforier af få dages varighed, hvorunder han lå bortgemt i sin seng og bl. a. slugte det halve skaft af en theske. Han blev efter ophold $\mathrm{i}$ familiepleje endeligt udskrevet 32 år gammel og var derefter beskæftiget ved landbrug, påbegyndte 43 år gammel kyllingeopdræt, men kunne ikke klare de $\phi$ konomiske forpligtelser. Han blev deprimeret og suicidaltruende og var 2 gange indlagt for en psykogen depression. Han klarede sig uden kriminelt recidiv til sin d $\varnothing \mathrm{d}$ 30 år efter udskrivelsen fra Sikringsanstalten.

Medens mange patienter i forbindelse med deres voldsomme aggressive adfærd samtidig har været truende, har kun 15 patienter $(7 \%)$ været indlagt på grund af trusler alene. Som regel har det da været alvorligt lydende og gentagne trusler på livet overfor personalet i institutioner. Der er også forekommet trusler om ildspåsættelse.

13 patienter var indlagt i Sikringsanstalten for voldtægt. Heraf var 8 patienter psykopater, der således ved deres hyppighed adskiller sig signifikant fra resten $(\mathrm{p}<0,001)$.

Sygehistorie S.A. nr. 58:

29-årig holdningsløs, hyperseksuel psykopat og alkoholist, der efter indbrud og voldtægt udviklede en depressiv psykogen psykose $\mathrm{i}$ fængslet, $\mathrm{i}$ hvilken han suiciderede. Da han begik voldtægten, var han ikke psykotisk. 
Faderen var fordrukken, moderen og en broder tidligere indlagt på psykiatrisk hospital for psykose, en broder straffet for dyremishandling. Patienten voksede op $\mathrm{i}$ dårlige forhold som $\mathrm{nr} .2$ af 8 , klarede sig dårligt i landsbyskole, var hidsig og stridbar og havde senere kun kortvarige ansættelser. I 17-18 års alderen var han indlagt på psykiatrisk hospital for en psykogen psykose, og senere blev han temmelig drikfældig, og under indflydelse af alkohol var han meget seksuelt aktiv.

24 år gammel blev han gift og tjente hovedsagelig på herregårde, hvor han ofte kom i dårligt selskab og fik for meget at drikke. Overfor hustruen var han ret seksuelt krævende, og hun afviste ham ofte, når han var fuld, da hun frygtede graviditet. Han s $\varnothing$ gte andre kvinder, og 27 år gammel begik han i fuldskab indbrud hos en enligt boende lærerinde, som han voldtog. I arresten var han den første tid rolig, men herefter snart glad og opstemt, snart ulykkelig og grædende, ligesom han tilstod flere tilfælde af brandstiftelse og voldtægt $i$ beruset tilstand. Han blev id $\phi \mathrm{mt} 5$ års forbedringshusarbejde, men overflyttedes samme år til statshospital, da han var psykotisk; ind imellem h $\varnothing$ relseshallucineret, grædende og undertiden religi $\varnothing s t$ eksalteret. Han var tillige selvmutilerende og fors $\varnothing$ gte suicidium ved at stoppe et lommet $\varnothing$ rklæde $\mathrm{i}$ halsen.

Han blev derfor 29 år gammel overflyttet til Sikringsanstalten, hvor han virkede deprimeret og talte om, at nogle stemmer i hovedet sagde til ham, at han skulle halshugges. Det lykkedes patienten efter 14 dages ophold at suicidere ved at hænge sig i et lagen fastgjort til jerngitteret $\mathrm{i}$ vinduet.

Patienten opfattedes som konstitutionel psykopat af den holdningsløse, affektlabile type og seksuelt hyperaktiv. Han var desuden alkoholist.

Endelig var 14 patienter indlagt på grund af forskellige andre forhold. Det drejede sig om 6 patienter med psykoser opstået i fængsel og 5 patienter med suicidal- og/eller flugtfors $\varnothing \mathrm{g}$ i fængsler. De sidste 3 patienter omfatter en patient (S.A. nr. 213), der under 2. verdenskrig indfandt sig på Hotel d'Angleterre i København med en buket roser og en $\phi \mathrm{kse}$ for at slå en tysk general ihjel. Den anden patient (S.A. nr. 37) indlagdes på grund af udtalt ekshibitionisme. Den tredie (S.A. nr. 50) havde været både på psykiatriske hospitaler og åndssvageinstitutioner, idet der herskede usikkerhed med hensyn til hans placering. Han betragtedes som farlig, da han var ret vanskelig i disse institutioner, og han havde skrevet trusselsbreve både til Kongen og justitsministeren.

Patienternes motivdannelse ved den farlige handling er vanskelig at vurdere statistisk, da oplysningerne herom ikke er tilstræk- 
keligt fyldestg $\varnothing$ rende. De i det foregående anf $\phi$ rte syv sygehistorier giver dog et indtryk af problemet.

4 patienter har alle begået mord. Af disse var nr. $13 \mathrm{og} \mathrm{nr.} 93$ i en sygelig bevidsthedstilstand på gerningstidspunktet. Nr. 13 synes helt at mangle motiv. Han handlede formentlig i en abnorm bevidsthedstilstand på grund af beruselse eller epilepsi. Han havde drukket rigeligt $\mathrm{i}$ en årrække, og en ændret reaktionsmåde overfor alkohol er en mulig forklaring på hans handling, hvorimod efterforl $\phi$ bet ikke tydede på, at han var epileptiker.

Nr. 93 var epileptiker og handlede i en præparoxystisk dysfori, hvor han i $\varnothing$ vrigt var klar, men overordentlig affektpirrelig.

Nr. 98 og nr. 197 var begge paranoide, skizofrene patienter, der syntes at handle under indflydelse af deres vrangforestillinger nr. 41 var også skizofren, men hans motivdannelse kan ikke nærmere vurderes.

De to sidst refererede patienter havde mere klare motiver. Nr. 82 var småt begavet og anstiftede brand i tilslutning til forurettelser og modgang. Nr. 58 var en holdningsl $\phi$ s psykopat og alkoholist med meget stærk k $\phi$ nsdrift, som i beruselse foretog voldtægt.

Sociale og andre præmorbide forhold.

\section{De sociale forhold:}

Til belysning af patienternes sociale baggrund kan anf $\phi \mathrm{res} f \phi \mathrm{l}-$ gende data: Rubriceret efter erhverv var 142 patienter $(70 \%)$ ufaglærte arbejdere, 25 patienter $(12 \%)$ var faglærte. 18 patienter $(9 \%)$ havde intet erhverv. Yderligere 18 patienter fordelte sig med 8 patienter i liberale erhverv, 5 patienter i funktionærstillinger og 5 akademikere. En sikker forskel på diagnosegrupperne i denne henseende findes ikke.

Sikringsanstaltens klientel må iøvrigt i social henseende betegnes som meget tungt. 31 patienter $(15 \%)$ er således f $\varnothing \mathrm{dt}$ udenfor ægteskab. 39 patienter (19\%) har under opvæksten været anbragt i forskellige institutioner. 7 patienter kom fra brudte hjem. Dårlige forhold $\mathrm{i}$ barndommen er yderligere fundet hos 76 patienter $(37 \%) .26$ patienter $(13 \%)$ måtte efter det foreliggende betegnes som asociale. 67 patienter (33\%) var ustabile arbejdere med hyppigt skiftende, kortvarige ansættelser.

Hos i alt 146 patienter ( $72 \%$ ) er der registreret dårlige sociale forhold under den ene eller den anden form, medens de resterende 57 patienter ikke har frembudt sådanne forhold. Sammenligner man disse to grupper med hensyn til diagnoser og farlige handlinger fås $f \varnothing l g e n d e$ resultater: 
Tabel 6. Patienter med og uden dårlige sociale forhold (d.s.f.) fordelt efter diagnoser.

\begin{tabular}{lrrr}
\hline & $\begin{array}{c}\text { med } \\
\text { d.s.f. }\end{array}$ & $\begin{array}{l}\text { uden } \\
\text { d.s.f. }\end{array}$ & total \\
\hline Skizofreni & 56 & 35 & 91 \\
Psykopati & 52 & 6 & 58 \\
Epilepsi & 11 & 8 & 19 \\
Psykogen psykose & 10 & 2 & 12 \\
Oligofreni & 10 & 1 & 11 \\
Andre & 7 & 5 & 12 \\
\hline I alt & 146 & 57 & 203
\end{tabular}

Der er forholdsvis flere psykopater og færre skizofrene i den socialt dårlige gruppe, hvor også næsten alle patienter med diagnosen oligofreni findes (tabel 6 ). De skizofrene patienter adskiller sig signifikant fra resten $(\mathrm{p}<0,01)$, og det samme gælder $i$ endnu højere grad for psykopaterne $(p<0,001)$. For de oligofrenes vedkommende kan en sådan sikker forskel ikke påvises $(0,10<\mathrm{p}<0,95)$.

En tilsvarende sammenstilling af relationen mellem dårlige sociale forhold og de farlige handlingers art viser ingen statistisk signifikante forskelle.

Medens der altså synes at bestå en relation mellem dårlige sociale forhold og arten af den psykiske lidelse, spiller de dårlige sociale forhold åbenbart ingen rolle for den farlige handlings art i dette materiale.

\section{Væsentlige karaktertræk og andre præmorbide forhold:}

Sk $\phi$ nt en n $\varnothing$ jere karakterologisk analyse af patienterne i dette materiale på grund af utilstrækkelige oplysninger ikke er mulig, er det alligevel af interesse at fors $\phi$ ge en grov karakteristik af den præmorbide psykiske udrustning hos patienterne (tabel 7).

De fleste er registreret med det mest markante træk, men mange med flere. Nogle patienter har endvidere bidiagnoserne: karakterdefekt, intelligensdefekt og alkoholisme.

Der er 161 patienter (79\%) med oplysninger om præmorbide træk, incl. de nævnte bidiagnoser, og 42 patienter $(21 \%$ ) uden sådanne oplysninger. Blandt de skizofrene mangler sådanne oplysninger hos 30 , hvilket er flere end blandt resten $(p<0,01)$. Psykopaterne er i journalerne mest indgående beskrevet med hensyn til karaktertræk. Oplysninger herom findes hos langt de fleste, nemlig 56 af de 58 patienter $(p<0,001)$. 25 er karakteriseret ved mere end et beskrivende adjektiv. Holdningsl $\varnothing$ shed 
Tabel 7. Væsentligste præmorbide karaktertræk.

\begin{tabular}{|c|c|c|}
\hline Holdningsl $\varnothing$ shed & 56 & ptt. \\
\hline Eretisme & 39 & „, \\
\hline Affektlabilitet & 32 & , \\
\hline Selvhævdelse & 31 & „, \\
\hline Skizotymi & 25 & „, \\
\hline Sensitivitet & 13 & , \\
\hline Dysfori & 3 & $"$ \\
\hline Cyklotymi & 3 & ", \\
\hline Depressivitet & 2 & „, \\
\hline Selvusikkerhed & 2 & , \\
\hline Følelseskulde & 2 & $"$ \\
\hline Psykoinfantilisme & 2 & ” \\
\hline Upålidelighed & 1 & ” \\
\hline
\end{tabular}

fandtes hos knapt halvdelen, medens selvhævdelse, affektlabilitet og eretisme hver for sig blev fundet hos ca. en trediedel, naturligvis ofte i kombination, idet de tilsammen omfatter 48 patienter. De $\varnothing$ vrige 8 udg $\phi$ res af 3 sensitive, 2 psykoinfantile, 2 f $\phi$ lelseskolde og een, der anses for hovedsagelig upålidelig.

Karakterafvigelse som bidiagnose fandtes hos 11 af 12 patienter med psykogen psykose (oftest sensitivitet), hos 8 af 19 epileptikere (oftest affektlabilitet og eretisme), og hos 28 skizofrene (oftest skizotyme træk).

Foruden de 11 patienter med hoveddiagnosen oligofreni blev 33 patienter ( $16 \%$ ) betegnet som intelligensdefekte. Blandt disse var 15 psykopater og 11 skizofrene.

Hos 35 patienter (17\%) havde der været et spiritusmisbrug. Det ret lave tal skyldes måske utilstrækkelige oplysninger. Af disse patienter var 15 psykopater og 10 skizofrene. For begge disse grupper er der således hyppigere spiritusmisbrug end blandt resten, hvilket er statistisk signifikant (i begge tilfælde fås $\mathrm{p}<$ $0,05)$. Mere avanceret medicinmisbrug endsige narkomani foreligger slet ikke blandt vore patienter.

\section{Den aldersmæssige fordeling.}

a. Alder ved sygdomsudbruddet:

Patienternes alder ved sygdomsudbruddet er i det store og hele registreret som alderen ved f $\phi$ rste indlæggelse. Psykopaterne og de oligofrene patienter har det kun været muligt at registrere som værende syge $f \varnothing r$ det 20 . år. I alt 166 patienter $(82 \%)$ var syge, f $\varnothing \mathbf{r}$ de fyldte 30 år. Kun ganske få blev syge i senere alder, således kun 8 patienter $(4 \%)$ ved 40 års alderen eller senere (fig. 2). 


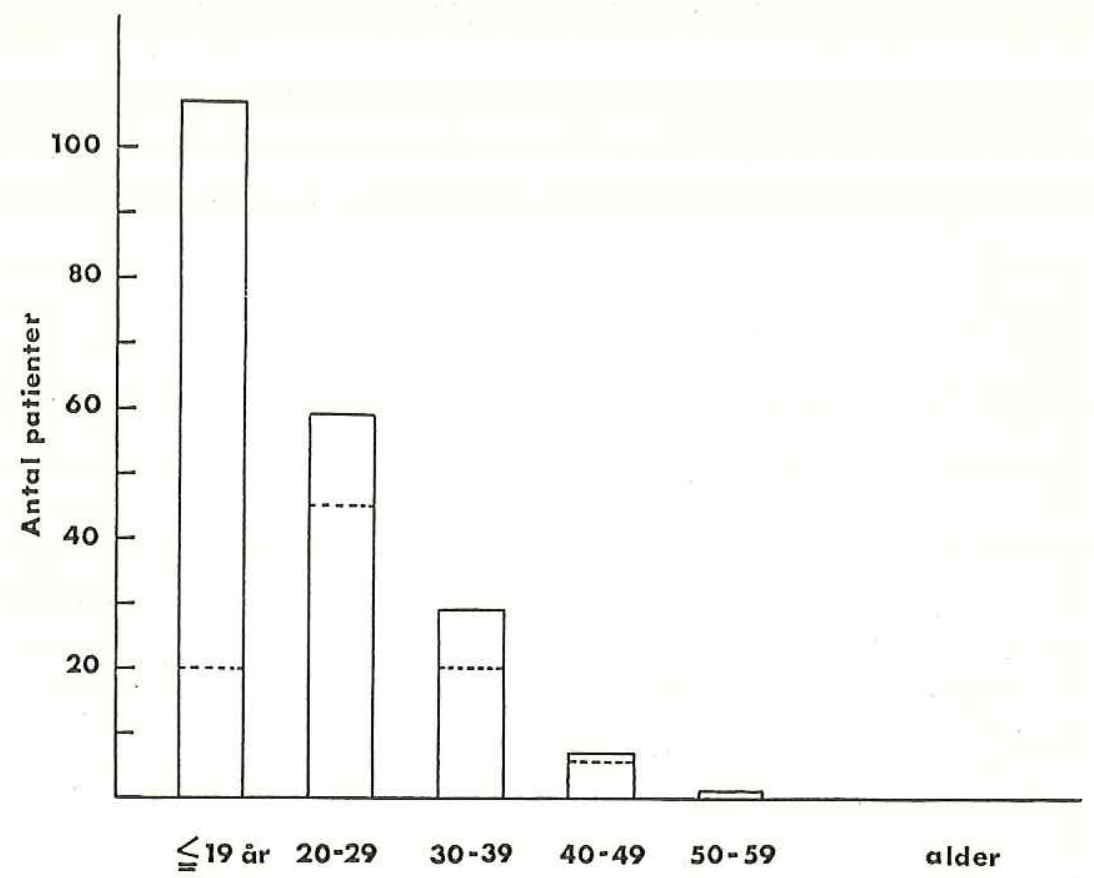

Fig. 2. Alder ved sygdommens begyndelse for total-materialet ( $\longrightarrow$ ) og skizofrene (----).

Psykopaterne og de oligofrene påvirker selvsagt materialet med hensyn til alderen ved sygdommens begyndelse. Ser man imidlertid bort fra disse patienter og sammenligner de skizofrene med resten, fås ingen forskel $\mathrm{i}$ denne henseende $(0,95>\mathrm{p}>0,10)$.

Blandt de 91 skizofrene begyndte sygdommen $\mathrm{f} \phi \mathrm{r}$ det 20 . år hos 20 patienter (22\%), og yderligere blev 45 patienter $(49 \%)$ syge inden det 30 . år, således at $\mathrm{i}$ alt $71 \%$ var syge ved 30 års alderen. Derimod opstod ingen skizofreni efter det 50. år.

\section{b. Alderen ved første kriminalitet:}

156 patienter (77\%) havde været kriminelle, inden de foretog den farlige handling, der medf $\varnothing$ rte deres anbringelse i Sikringsanstalten. For de resterende 47 patienter (23\%) var den farlige handling også første lovovertrædelse.

Sammenligner man de 47 patienter, som ikke var kriminelle f $\varnothing \mathbf{r}$ den farlige handling, med resten, finder man, at de hyppigt var omkring 30 år, men med ret stor spredning, medens de $\varnothing$ vrige patienter fortrinsvis grupperer sig omkring 20 års alderen og 
Tabel 8. Patienternes alder ved første lovovertrædelse.

\begin{tabular}{lccr}
\hline Alder & $\begin{array}{c}\text { 1. lovovertrædelse } \\
\text { ulig farlige handling. }\end{array}$ & $\begin{array}{c}\text { 1. lovovertrædelse } \\
\text { = farlige handling. }\end{array}$ & total \\
\hline Under 20 år & 88 & 4 & 92 \\
$20-29$ år & 51 & 14 & 65 \\
$30-39 ”$ & 12 & 14 & 26 \\
$40-49 ”$ & 5 & 11 & 16 \\
$50-59 ”$ & 0 & 4 & 4 \\
$60+$ & 0 & 0 & 0 \\
\hline I alt & 156 & 47 & 203
\end{tabular}

med mindre udtalt spredning (tabel 8). Det er altså især de helt unge patienter, der har været kriminelle f $\phi \mathbf{r}$ den farlige handling. For patienter under 20 år er forskellen signifikant $(p<0,001)$. Også i diagnostisk henseende $g \varnothing r$ der sig visse forskelle gældende (tabel 9).

Tabel 9. Diagnoser i relation til f $\varnothing$ rste lovovertrædelse.

\begin{tabular}{lccc}
\hline Diagnose & $\begin{array}{c}\text { 1. lovovertrædelse } \\
\text { ulig farlige handling. }\end{array}$ & $\begin{array}{c}\text { 1. lovovertrædelse } \\
\text { = farlige handling. }\end{array}$ & total \\
\hline Skizofreni & 61 & 30 & 91 \\
Psykopati & 53 & 5 & 58 \\
Epilepsi & 13 & 6 & 19 \\
Psykogen psykose & 11 & 1 & 12 \\
Oligofreni & 10 & 1 & 11 \\
Andre & 8 & 4 & 12 \\
\hline I alt & 156 & 47 & 203
\end{tabular}

Der er relativt mange psykopater blandt patienter, der har været kriminelle $\mathrm{f} \phi \mathbf{r}$ den farlige handling, medens derimod gruppen af patienter, hvis første lovovertrædelse var den farlige handling, i h $\phi \mathbf{j}$ grad domineres af de skizofrene. Både psykopater og skizofrene adskiller sig herved signifikant fra resten $(\mathrm{p}<0,01)$.

Da alle patienter jo har foretaget en farlig handling, vil en opg $\phi$ relse af de tilfælde, hvor den f $\varnothing$ rste kriminelle handling er forskellig fra den farlige, formentlig være særdeles belysende for kriminaliteten i dette materiale (tabel 10).

Blandt de 61 skizofrene, som havde været lovovertrædere f $\phi \mathrm{r}$ den farlige handling, havde 24 patienter (40\%) været kriminelle f $\varnothing \mathbf{r}$ det 20 . år. Dette tal er signifikant lavere end for resten af patienterne $(\mathrm{p}<0,001)$. Blandt 53 tidligere kriminelle psyko- 
Tabel 10. Patienternes alder ved første lovovertrædelse, hvor denne er ulig den farlige handling.

\begin{tabular}{lrrrrrrr}
\hline Alder & $\begin{array}{c}\text { skizo- } \\
\text { freni }\end{array}$ & $\begin{array}{c}\text { psyko- } \\
\text { pati }\end{array}$ & $\begin{array}{c}\text { epi- } \\
\text { lepsi }\end{array}$ & $\begin{array}{c}\text { psykog. } \\
\text { psykose }\end{array}$ & $\begin{array}{c}\text { oligo- } \\
\text { freni }\end{array}$ & andet & total \\
\hline Under 20 år & 24 & 42 & 7 & 6 & 7 & 2 & 88 \\
$20-29$ år & 30 & 9 & 4 & 3 & 1 & 4 & 51 \\
$30-39 ”$ & 3 & 1 & 2 & 2 & 2 & 2 & 12 \\
$40-49 ”$ & 4 & 1 & 0 & 0 & 0 & 0 & 5 \\
$50-59 ”$ & 0 & 0 & 0 & 0 & 0 & 0 & 0 \\
$60+$ & 0 & 0 & 0 & 0 & 0 & 0 & 0 \\
\hline I alt & 61 & 53 & 13 & 11 & 10 & 8 & 156
\end{tabular}

pater havde 42 patienter (ca. $80 \%$ ) været kriminelle f $\varnothing \mathbf{r}$ det 20. år. Dette tal er signifikant større end for resten af patienterne $(\mathrm{p}<0,001)$.

Alt $\mathrm{i}$ alt findes hos de skizofrene patienter i dette materiale relativt sjældnere kriminalitet $\mathrm{f} \phi \mathrm{r}$ den farlige handling end hos de $\phi$ vrige patienter, og deres kriminalitet synes i mindre grad knyttet til gruppen under 20 år, end det er tilfældet for resten. Psykopaterne karakteriseres derimod sikkert ved en hyppig og tidlig kriminalitet $\mathrm{f} \phi \mathrm{r}$ den farlige handling.

\section{c. Alderen ved den farlige handling:}

Den aldersmæssige spredning er for den farlige handlings vedkommende ganske stor (tabel 11).

Tabel 11. Patienternes alder ved den farlige handling.

\begin{tabular}{lrrrrrrr}
\hline Alder & $\begin{array}{c}\text { skizo- } \\
\text { freni }\end{array}$ & $\begin{array}{c}\text { psyko- } \\
\text { pati }\end{array}$ & $\begin{array}{r}\text { epi- } \\
\text { lepsi }\end{array}$ & $\begin{array}{c}\text { psykog. } \\
\text { psykose }\end{array}$ & $\begin{array}{l}\text { oligo- } \\
\text { freni }\end{array}$ & andet & total \\
\hline Under 20 år & 2 & 7 & 3 & 0 & 2 & 0 & 14 \\
$20-29$ år & 29 & 27 & 6 & 5 & 5 & 3 & 75 \\
$30-39$, & 38 & 14 & 5 & 3 & 3 & 4 & 67 \\
$40-49$, & 19 & 9 & 5 & 3 & 1 & 4 & 41 \\
$50-59 \#$ & 3 & 1 & 0 & 0 & 0 & 1 & 5 \\
$60+$ & 0 & 0 & 0 & 1 & 0 & 0 & 1 \\
\hline I alt & 91 & 58 & 19 & 12 & 11 & 12 & 203
\end{tabular}

$90 \%$ af alle patienter var dog mellem 20 og 50 år, da de foretog den farlige handling. Kun een patient var over 60 år. Blandt de skizofrene var der færre under 30 år $(p<0,02)$ og blandt psykopater flere $(p<0,01)$ end blandt resten. 
Er der sammenhreng mellem sygdommens udbrud,
dens forl $\phi b$ og den farlige handling?

Dette spфrgsmål er s $\phi g t$ belyst ved en opg $\phi$ relse af, (a) efter hvor lang tids sygdom den farlige handling er foretaget; (b) hvor mange patienter, der tidligere har været indlagt i psykiatrisk hospitalsafdeling, og om disse adskiller sig fra patienter uden tidligere indlæggelse, samt (c) hvilke symptomer, der særlig har belastet patienterne.

a. Efter hvor lang tids sygdom foretages den farlige handling? Ved sygdommens varighed forstås her tiden fra sindssygdomssymptomers opståen eller første indlæggelse til tidspunktet for den farlige handling.

I tabel 12, der viser sygdomsvarigheden ved den farlige handling, er ikke medtaget psykopati og oligofreni, da man ikke har fundet det rimeligt eller muligt at fiksere manifestationstidspunktet for disse tilstande. Blandt resten - 134 - havde $97 \mathrm{pa-}$ tienter $(72 \%)$ været syge i mere end 5 år.

Tabel 12. Sikringsanstaltens patienter undtagen psykopater og oligofrene fordelt efter sygdommens varighed ved den farlige handling.

\begin{tabular}{lccccc}
\hline Varighed & $\begin{array}{c}\text { skizo- } \\
\text { freni }\end{array}$ & $\begin{array}{c}\text { epi- } \\
\text { lepsi }\end{array}$ & $\begin{array}{c}\text { psykog. } \\
\text { psykose }\end{array}$ & andre & total \\
\hline Ikke brudt ud & 0 & 0 & 2 & 0 & 2 \\
Akut & 3 & 0 & 2 & 1 & 6 \\
Under 1/2 år & 2 & 0 & 1 & 0 & 3 \\
1/2-1 år & 0 & 0 & 1 & 0 & 1 \\
$1-5$ ” & 21 & 2 & 0 & 2 & 25 \\
Over 5 år & 65 & 17 & 6 & 9 & 97 \\
\hline I alt & 91 & 19 & 12 & 12 & 134
\end{tabular}

Yderligere 25 patienter havde været syge i over et år, således at 122 patienter $(91 \%)$ havde været syge i mere end et år.

Kun 2 patienter begik den farlige handling på et tidspunkt, hvor de endnu var raske. 6 patienter foretog den farlige handling i sygdommens akutte fase, og heraf var 3 skizofrene.

Sammenligner man de 91 skizofrene patienter med de resterende 43 , fås ingen signifikant forskel med hensyn til sygdomsvarighed over eller under 5 år $(0,95>p>0,10)$. Derimod synes der at være relativt få skizofrene, der har været syge $i$ et år eller mindre ved den farlige handling $(\mathrm{p}<0,05)$.

17 af 19 epileptikere foretog den farlige handling efter mere 
end 5 års sygdom, hvilket ikke er signifikant flere end blandt de $\phi$ vrige patienter $(0,95>\mathrm{p}>0,10)$.

Blandt de 12 patienter med psykogene psykoser havde halvdelen været syge $\mathrm{i}$ over 5 år. Sammenlignet med de resterende 122 patienter er der en tendens til relativt kortvarige sygdomsforl $\phi b$ forud for den farlige handling $(0,10>p>0,05)$.

Af 26 skizofrene, der havde været syge mindre end 5 år, havde $12(48 \%)$ begået grov vold. Dette var også tilfældet for $49(75 \%)$ af 65 skizofrene, hvis sygdom havde varet over 5 år.

Blandt de skizofrene er antallet af patienter, der har begået grove voldshandlinger, altså størst ved mere end 5 års sygdomsvarighed $(\mathrm{p}<0,01)$. Sådanne forskelle kan ikke påvises ved andre kategorier af farlige handlinger.

b. Hvor mange patienter har før den farlige handling været indlagt på en psykiatrisk hospitalsafdeling?

Adskiller patienterne med et sådant ophold sig fra patienter uden?

Da langt de fleste patienter har foretaget den farlige handling efter længere tids sygdom, kunne man formode, at et stort antal tidligere har været indlagt i psykiatrisk hospitalsafdeling. Det viser sig da også, at $\mathrm{i}$ hele materialet har 115 patienter $(57 \%)$ haft et længere eller kortere ophold i psykiatrisk hospitalsafdeling.

Tabel 13. Den diagnostiske fordeling i relation til tidligere indlæggelse i psykiatrisk hospital.

\begin{tabular}{lrrr}
\hline Diagnose & $\div$ hosp. & + hosp. & total \\
\hline Skizofreni & 21 & 70 & 91 \\
Psykopati & 44 & 14 & 58 \\
Epilepsi & 3 & 16 & 19 \\
Psykogen psykose & 7 & 5 & 12 \\
Oligofreni & 7 & 4 & 11 \\
Andre & 6 & 6 & 12 \\
\hline I alt & 88 & 115 & 203
\end{tabular}

I tabel 13 ses, at der blandt de skizofrene er flere med end uden tidligere hospitalsophold $(\mathrm{p}<0,001)$, og blandt psykopaterne flest uden tidligere hospitalsophold $(\mathrm{p}<0,001)$. Også blandt epileptikerne er der flest med et tidligere psykiatrisk hospitalsophold $(\mathrm{p}<0,05)$.

Hvad angår fordelingen af farlige handlinger (tabel 14), finder man, at der blandt patienter, der tidligere har været indlagt i psykiatriske hospitalsafdelinger, er et relativt stort antal med 
grove voldshandlinger af farlig karakter. Det drejer sig om 79 patienter, hvorimod der kun er 22 i gruppen uden tidligere hospitalsophold. Forskellen er statistisk signifikant $(p<0,001)$.

Blandt de patienter, der ikke har et forudgående hospitalsophold, er der relativt flere tilfælde af mord og mordfors $\phi g$ $(\mathrm{p}<0,001)$, brandstiftelse $(\mathrm{p}<0,001)$ og voldtrgt $(\mathrm{p}<0,001)$.

Tabel 14. De farlige handlinger i relation til tidligere indlæggelse i psykiatrisk hospital.

\begin{tabular}{lccr}
\hline Gerningens art & $\div$ hosp. & + hosp. & total \\
\hline Mord og mordfors $\phi \mathrm{g}$ & 30 & 14 & 44 \\
Grove voldshandlinger & & & \\
af farlig karakter & 22 & 79 & 101 \\
Brandstiftelse & 22 & 2 & 29 \\
Voldtægt & 11 & 14 & 13 \\
Grove trusler alene & 1 & 3 & 15 \\
Andet & 11 & 119 & 14 \\
\hline I alt & 97 & 4 & 216 \\
Flere farlige handlinger & 9 & 115 & 13 \\
\hline Total & 88 & & 203
\end{tabular}

Hvad specielt de skizofrene angår, har 61 patienter foretaget grove voldshandlinger af farlig karakter. Blandt disse var 10 patienter uden og 51 patienter med et tidligere ophold. Der er således signifikant flest patienter med et tidligere hospitalsophold $(\mathrm{p}<0,05)$.

\section{c. Hvilke symptomer har særligt belastet patienterne på} tidspunktet for den farlige handling?

Af tabel 15 ses, at man kun i 3 tilfælde har anset den farlige handling for en psykologisk forståelig reaktion på et adækvat psykisk traume, og at man hos kun 29 patienter har noteret tegn pá en oprevet, spændt sjælelig tilstand forud for den farlige handling.

Spirituspåvirkning, der sædvanligvis spiller en stor rolle for kriminalitet, har her haft en underordnet betydning, idet kun 13 patienter $(6 \%)$ var berusede på gerningstidspunktet og ingen havde patologisk rus. Ingen var medicinpåvirkede $\mathrm{i}$ forbindelse med den farlige handling.

Mere end halvdelen af de skizofrene patienter havde paranoide forestillinger, oftest af persekutiv natur, medens knapt halvdelen var hallucinerede, hyppigst på hørelsen. 
Tabel 15. 114 patienter fordelt efter de på tidspunktet for den farlige handling særligt belastende symptomer.

Paranoide forestillinger

Hørelses- og/eller synshallucinationer

Andre påvirkningsfornemmelser

Oprevet sindstilstand

Spirituspåvirkning

„Adækvat" psykisk traume
$63 \mathrm{ptt}$.

49 ,

11 ”

29,

13 ,

3 ”
$31 \%$

$24 \%$

$5 \%$

$14 \%$

$6 \%$

$1 \%$

Adskillige patienter har frembudt et kompleks af symptomer ved den farlige handling. De 114 patienter, hvis akter giver oplysninger herom, omfatter 76 skizofrene, der udg $\varnothing \mathrm{r}$ en gruppe stor nok til nærmere vurdering.

I tabel 16 ses, at disse patienter ganske overvejende frembyder symptomer som paranoide forestillinger og hallucinationer, der er noteret hos hhv. $53 \mathrm{og} 46$ patienter, men i alt omfatter 68 patienter.

Tabel 16. 76 skizofrene patienter fordelt efter fremtrædende symptomer i relation til den farlige handlings art.

\begin{tabular}{lcccccc}
\hline Gerningens art & $\begin{array}{c}\text { para- } \\
\text { noid }\end{array}$ & $\begin{array}{c}\text { halluci- } \\
\text { neret }\end{array}$ & $\begin{array}{c}\text { andre } \\
\text { påvirkn. }\end{array}$ & $\begin{array}{c}\text { oprevet } \\
\text { sindstilst. }\end{array}$ & spir. & $\begin{array}{c}\text { adækvat } \\
\text { traume }\end{array}$ \\
\hline $\begin{array}{l}\text { Mordfors } \varnothing \mathrm{g} \\
\text { Grove voldshandlinger }\end{array}$ & 9 & 7 & 2 & 2 & 2 & 0 \\
af farlig karakter & 38 & 33 & 7 & 8 & 2 & 1 \\
Brandstiftelse & 3 & 5 & 2 & 1 & 1 & 0 \\
Voldtægt & 0 & 1 & 0 & 1 & 1 & 0 \\
Grove trusler alene & 2 & 0 & 0 & 0 & 0 & 0 \\
Andet & 1 & 1 & 0 & 0 & 0 & 0
\end{tabular}

I alt 55 af disse 76 patienter har foretaget grove voldshandlinger. Der er imidlertid ingen påviselig sammenhæng mellem på den ene side paranoide forestillinger og hallucinationer og på den anden side grove voldshandlinger $(0,95>p>0,10)$.

\section{Anbringelsesmåden.}

Patienterne anbringes i Sikringsanstalten enten ved dom eller ved justitsministeriel resolution (administrativt).

123 patienter $(61 \%)$ er administrativt anbragte. Som det ses af tabel 17, er det især de skizofrene, der anbringes administrativt, nemlig 67 patienter $(74 \%)$. Sammenlignet med de $\varnothing$ vrige patienter er denne forskel mellem administrativt anbragte og domsanbragte paitenter signifikant $(\mathrm{p}<0,001)$. 
Tabel 17. Anbringelsesmåden i relation til diagnoser.

\begin{tabular}{lrcr}
\hline Diagnoser & dom & administrativt & total \\
\hline Skizofreni & 24 & 67 & 91 \\
Psykopati & 34 & 24 & 58 \\
Epilepsi & 9 & 10 & 19 \\
Psykogene psykoser & 6 & 6 & 12 \\
Oligofreni & 4 & 7 & 11 \\
Andre & 3 & 9 & 12 \\
\hline I alt & 80 & 123 & 203
\end{tabular}

Derimod anbringes psykopaterne overvejende efter dom eller kendelse, hvilket gælder 34 psykopater (59\%). Forskellen mellem disse og de $\varnothing$ vrige patienter er også her signifikant $(p<$ 0,001). For de mindre diagnosegrupper er der iklke signifikante forskelle.

Dette er formentlig et udtryk for, at de skizofrene patienter oftere end psykopaterne er anbragt i hospital, når de begår den farlige handling, der f $\varnothing$ rer dem til Sikringsanstalten.

Tabel 18. Anbringelsesmåden i relation til de farlige handlinger.

\begin{tabular}{lrrr}
\hline Gerningens art & dom & administrativt & total \\
\hline Grove voldshandlinger af & & & \\
farlig karakter & 24 & 77 & 101 \\
Mord og mordfors $\varnothing \mathrm{g}$ & 27 & 17 & 44 \\
Brandstiftelse & 17 & 12 & 29 \\
Grove trusler alene & 5 & 10 & 15 \\
Voldtægt & 9 & 4 & 13 \\
Andet & 6 & 8 & 14 \\
\hline I alt & 88 & 128 & 216 \\
Flere farlige handlinger & 8 & 5 & 13 \\
\hline Total & 80 & 123 & 203
\end{tabular}

Grove voldshandlinger af farlig karakter er især begået af de administrativt anbragte patienter $(p<0,001)$, og dette gælder også blandt de administrativt anbragte skizofrene $(p<0,01)$. Mord og mordfors $\phi \mathrm{g}$ er især foretaget af de domsanbragte $(\mathrm{p}<$ 0,001 ), men hvad netop disse handlinger angår, adskiller f. eks. de domsanbragte psykopater sig ikke sikkert fra de administrativt anbragte psykopater $(0,10>p>0,05)$. Vedrørende hver af de $\phi$ vrige kategorier af farlige handlinger er der ingen signifikant forskel. 
Tabel 19. Anbringelsesmåden i relation til tidsgrupperne.

\begin{tabular}{lccccr}
\hline & A & B & C & D & total \\
\hline dom & 11 & 17 & 23 & 28 & 80 \\
administrativt & 39 & 33 & 26 & 26 & 123 \\
\hline I alt & 50 & 50 & 49 & 54 & 203
\end{tabular}

Med hensyn til tidligere kriminalitet er der ingen forskel på de domsanbragte og de administrativt anbragte patienter $(0,95>$ $\mathrm{p}>0,10)$.

I tabel $19 \mathrm{er}$ anbringelsesmåden sat i relation til tidsgrupperne.

Den i denne tabel viste fordeling er ikke, som man skulle vente, hvis forholdet mellem de domsanbragte og administrativt anbragte patienter til alle tider var nogenlunde konstant, og forskellen herfra er statistisk signifikant $(p<0,01)$. Det ses, at administrativ anbringelse i de ældste grupper A og B var langt den hyppigste, hvilket i de 2 yngste grupper har ændret sig, săledes at der i gruppe D er flest domsanbragte patienter.

\section{Terapien $i$ Sikringsanstalten.}

Behandlingen af Sikringsanstaltens patienter har naturligvis ændret sig gennem tiderne. I de f $\varnothing$ rste år kunne man hovedsagelig byde på isolering, sengeleje, pacificerende medikamentel behandling og arbejdsterapi. Senere fulgte krampebehandling, lobotomi og psykofarmaka i takt med udviklingen i andre psykiatriske institutioner.

De fleste patienter har fået en kombination af forskellige behandlingsformer. At patienterne kan frembyde store terapeutiske vanskeligheder (vægring, manglende kooperation eller motivation for behandling etc.) fremgår af, at 19 patienter ikke har fået terapi af den i tabel 20 nævnte karakter.

Tabel 20. 184 patienter fordelt efter de anvendte behandlingsformer.

\begin{tabular}{|c|c|c|c|c|c|c|c|}
\hline & $\begin{array}{l}\text { skizo- } \\
\text { freni }\end{array}$ & $\begin{array}{c}\text { psyko- } \\
\text { pati }\end{array}$ & $\begin{array}{l}\text { epi- } \\
\text { lepsi }\end{array}$ & $\begin{array}{l}\text { psykog. } \\
\text { psykoose }\end{array}$ & $\begin{array}{l}\text { oligo- } \\
\text { freni }\end{array}$ & andet & total \\
\hline Beskæftigelse & 41 & 47 & 15 & 8 & 10 & 8 & 129 \\
\hline $\begin{array}{l}\text { Sedativa og hypno- } \\
\text { tika } \\
\text { Moderne psyko- }\end{array}$ & 39 & 33 & 18 & 7 & 5 & 6 & 108 \\
\hline farmaka & 34 & 7 & 4 & 3 & 0 & 3 & 51 \\
\hline Krampebehandling & 15 & 0 & 0 & 2 & 0 & 1 & 18 \\
\hline Lobotomi & 12 & 1 & 1 & 0 & 0 & 0 & 14 \\
\hline Kastration & 1 & 1 & 0 & 2 & 0 & 0 & 4 \\
\hline
\end{tabular}


Beskæftigelsesterapi er den hyppigst anvendte terapiform. $64 \%$ af samtlige patienter har deltaget heri. Af de 91 skizofrene patienter har $41(45 \%)$ været i beskæftigelsesterapi, medens 50 ikke har kunnet beskæftiges. Der er således blandt de skizofrene flere ikke-beskæftigede patienter end blandt resten $(p<0,001)$. Blandt psykopaterne derimod har 47 patienter eller $81 \%$ været beskæftiget, medens 11 ikke har kunnet deltage heri, hvilket er signifikant færre ikke-beskæftigede end blandt resten $(p<0,01)$.

Medikamentel behandling har været anvendt i stor udstrækning, almindelige sedativa og hypnotika (brom, barbitursyrepræparater, skopolamin o. l.) således i mere end halvdelen af tilfældene. 39 skizofrene har fået denne behandling, hvilket er relativt færre end blandt de $\phi$ vrige patienter $(p<0,01)$.

De nye psykofarmaka er efterhånden givet til en fjerdedel af alle patienter og indtager nu en dominerende stilling i terapien. De første år anvendtes især reserpin, men senere er man mere og mere gået over til fentiazin-derivaterne. Blandt de skizofrene har 34 patienter $(37 \%)$ været behandlet med moderne psykofarmaka, hvilket er relativt flere end blandt resten $(p<0,001)$. Derimod har kun få psykopater fået denne behandling $(\mathrm{p}<0,01)$.

Krampebehandling, der overvejende er givet i form af elektroshock, er anvendt til i alt 18 patienter, hvoraf de 15 var skizofrene. Det lave tal afspejler måske de oprindeligt dårlige faciliteter i denne henseende i Sikringsanstalten. Lobotomi er anvendt til 14 patienter, hvoraf 12 var skizofrene. 4 patienter er blevet kastreret.

Foruden de nævnte terapiformer har alle patienter fået individuel psykologisk-pædagogisk behandling i den udstrækning og i den form, som man har fundet mest hensigtsmæssig og gennemf $\phi$ rlig.

Varigheden af opholdet $i$ Sikringsanstalten.

Registreringen af opholdets varighed anf $\varnothing$ res kun for de udskrevne patienter, hvor opholdet er afsluttet.

Af tabel 21 ses, at 158 patienter (78\%) er udskrevet fra Sikringsanstalten på skæringsdagen. 25 patienter var d $\phi$ de i Sikringsanstalten, og 20 patienter var indlagte på opg $\varnothing$ relsestidspunktet. Blandt samtlige udskrevne har 11 patienter $(7 \%)$ været indlagt i mindre end 1 år, og omtrent lige så mange har været indlagt i mere end 20 år. Resten fordeler sig der imellem med ca. $50 \%$ med ophold på $1-5$ år og godt $1 / 3$ i $6-20$ år.

For de 67 skizofrene patienter har den gennemsnitlige indlæggelsestid været større end for materialet som helhed, idet der er relativt få korte og relativt mange langvarige ophold. 23 patienter var indlagt i 5 år eller mindre, medens 44 patienter var indlagt $\mathrm{i}$ over 5 år. De skizofrene patienter adskiller sig i denne 
Tabel 21. Opholdstiden i Sikringsanstalten for de på skæringsdagen udskrevne 158 patienter.

\begin{tabular}{lrrrrrrr}
\hline & $\begin{array}{c}\text { skizo- } \\
\text { freni }\end{array}$ & $\begin{array}{c}\text { psyko- } \\
\text { pati }\end{array}$ & $\begin{array}{r}\text { epi- } \\
\text { lepsi }\end{array}$ & $\begin{array}{c}\text { psykog. } \\
\text { psykose }\end{array}$ & $\begin{array}{c}\text { oligo- } \\
\text { freni }\end{array}$ & andet & total \\
\hline Under 1 år & 2 & 6 & 2 & 0 & 0 & 1 & 11 \\
$1-2$ år & 8 & 17 & 3 & 4 & 5 & 1 & 38 \\
$3-5$, & 13 & 15 & 2 & 3 & 4 & 3 & 40 \\
$6-10 "$, & 12 & 10 & 3 & 2 & 1 & 1 & 29 \\
$11-20 "$, & 21 & 1 & 2 & 3 & 1 & 0 & 28 \\
over 20 år & 11 & 0 & 0 & 0 & 0 & 1 & 12 \\
\hline I alt & 67 & 49 & 12 & 12 & 11 & 7 & 158
\end{tabular}

henseende signifikant fra de $\phi$ vrige $(p<0,001)$. Omvendt forholder det sig med psykopaterne, blandt hvem de relativt korte ophold dominerer. 38 patienter var indlagte i 5 år eller mindre, og 11 var indlagte $\mathrm{i}$ over 5 år. Sammenlignet med de $\varnothing$ vrige patienter er forskellen statistisk signifikant $(p<0,001)$. Forskellene bliver særlig markante, når man sammenligner antallet af patienter behandlet i Sikringsanstalten i mere end 10 år. I det samlede materiale har ca. $25 \%$ været indlagt i over 10 år, hvilket er tilfældet for ca. $50 \%$ af de skizofrene, men kun for $2 \%$ af psykopaterne.

De $\phi$ vrige diagnostiske grupper er for små til statistisk vurdering af opholdets længde.

Tabel 22. Relationen mellem tidsgrupperne og opholdstiden i Sikringsanstalten blandt de 158 udskrevne patienter.

\begin{tabular}{lrrrrr}
\hline Opholdstid & A & B & C & D & total \\
\hline 2 år eller mindre & 10 & 15 & 12 & 12 & 49 \\
$3-5$ år & 9 & 10 & 9 & 12 & 40 \\
6 år eller mere & 21 & 17 & 21 & 10 & 69 \\
\hline I alt & 40 & 42 & 42 & 34 & 158
\end{tabular}

I tabel 22 er opholdstiden i Sikringsanstalten sat i relation til tidsepokerne. Den viste fordeling adskiller sig ikke signifikant fra, hvad man skulle forvente $(0,95>p>0,10)$. Måske er der lidt færre patienter med over 5 års ophold i gruppen $D$, hvilket kan skyldes, at denne gruppe er den yngste, eller at den moderne terapi $g \varnothing r$ sig gældende. 


\section{Efterundersфgelsen.}

\section{Observationstiden:}

Observationstiden for de 158 udskrevne patienter fremgår af tabel 23. Den er for den enkelte patient defineret som tidsforløbet fra udskrivelsen fra Sikringsanstalten indtil skæringsdagen eller til patientens $d \phi d$, hvis han er $d \phi d$ f $\phi \mathbf{r}$ denne dato.

Tabel 23. Observationstiden for de 158 patienter, der på skæringsdagen er udskrevet fra Sikringsanstalten.

\begin{tabular}{lrrrrrrr}
\hline Observationstid & $\begin{array}{c}\text { skizo- } \\
\text { freni }\end{array}$ & $\begin{array}{c}\text { psyko- } \\
\text { pati }\end{array}$ & $\begin{array}{r}\text { epi- } \\
\text { lepsi }\end{array}$ & $\begin{array}{c}\text { psykog. } \\
\text { psykose }\end{array}$ & $\begin{array}{c}\text { oligo- } \\
\text { freni }\end{array}$ & andet & total \\
\hline Under 1 år & 2 & 3 & 0 & 0 & 0 & 1 & 6 \\
$1-2$ år & 3 & 2 & 1 & 1 & 1 & 0 & 8 \\
$3-5$, & 19 & 4 & 5 & 2 & 0 & 0 & 30 \\
$6-10$, & 17 & 13 & 4 & 4 & 0 & 0 & 38 \\
$11-20$, & 18 & 12 & 2 & 4 & 2 & 3 & 41 \\
over 20 år & 8 & 15 & 0 & 1 & 8 & 3 & 35 \\
\hline I alt & 67 & 49 & 12 & 12 & 11 & 7 & 158
\end{tabular}

Kun 14 patienter (9\%) har en observationstid på mindre end 3 år. 114 patienter $(72 \%)$ har en observationstid på over 5 år. 76 patienter $(48 \%$ ) har en observationstid på over 10 år.

Hverken de skizofrene eller psykopaterne adskiller sig fra de $\phi$ vrige patienter med hensyn til observationstiden over og under 5 år.

\section{Behandlingsresultatet:}

Medens tidligere en del patienter blev udskrevet direkte til friheden, er gennem de sidste ca. 15 år alle fra Sikringsanstalten udskrevne patienter blevet udskrevet til andre psykiatriske institutioner, hvor behandlingen er blevet fortsat.

\section{a. Recidiv til farlige handlinger:}

Antallet af patienter, der har haft mulighed for et recidiv af denne art, omfatter de på skæringsdagen fra Sikringsanstalten udskrevne 158 patienter, hvortil kommer 2 patienter, der d $\varnothing$ de i Sikringsanstalten under deres anden indlæggelse, samt 3 patienter, der på skæringsdagen var indlagt i Sikringsanstalten og tidligere havde været der, altså $\mathrm{i}$ alt 163 patienter.

Blandt de på skæringsdagen udskrevne 158 patienter fandtes kriminelt recidiv i videste forstand (d. v. s. ufarligt + farligt recidiv) hos 37 patienter. Hertil kommer ovennævnte $2+3$ pa- 
tienter, og endelig er der 3 udskrevne, der alle har været indlagte i Sikringsanstalten mere end een gang, men som ikke er recidiveret efter sidste udskrivning fra Sikringsanstalten. I alt findes der således kriminelt recidiv i videste forstand hos 45 patienter. Dette giver en hyppighed af kriminelt recidiv i videste forstand på $28 \%$. Da næppe alle småforbrydelser er registreret, er angivelserne for disse formentlig minimumstal, hvorimod det er ret utænkeligt, at grove forbrydelser er overset.

Tabel 24. Arten og hyppigheden af recidiver hos de udskrevne patienter.

\begin{tabular}{|c|c|c|c|c|c|c|c|}
\hline & $\begin{array}{l}\text { skizo- } \\
\text { freni }\end{array}$ & $\begin{array}{c}\text { psyko- } \\
\text { pati }\end{array}$ & $\begin{array}{l}\text { epi- } \\
\text { lepsi }\end{array}$ & $\begin{array}{l}\text { psykog. } \\
\text { psykose }\end{array}$ & $\begin{array}{l}\text { oligo- } \\
\text { freni }\end{array}$ & andet & total \\
\hline Medrecidivmulighed & 69 & 50 & 13 & 12 & 11 & 8 & 163 \\
\hline \multicolumn{8}{|l|}{ farlige recidiver: } \\
\hline aggress. i hospital & 4 & 7 & 1 & & 3 & 2 & 17 \\
\hline anden „grov vold“ & 1 & 2 & 2 & & & & 5 \\
\hline mordfors $\varnothing \mathrm{g}$ & & 2 & & & & & 2 \\
\hline $\begin{array}{l}\text { brandstiftelse } \\
\text { uterlighed, voldtægt }\end{array}$ & & 1 & & & 1 & & 2 \\
\hline og fors $\varnothing \mathrm{g}$ herpå & & 2 & 1 & & 2 & & 5 \\
\hline mange tyverier & & 2 & & & & & 2 \\
\hline andet & 2 & & & & & & 2 \\
\hline total & 7 & 16 & 4 & 0 & 6 & 2 & 35 \\
\hline
\end{tabular}

ufarlige recidiver:

tyveri og indbrud

færdselsloven

bedrageri

andet

$\begin{array}{lll}4 & 1 & 5\end{array}$

2

1

total

$0 \quad 7$

7

Registrerede

recidiver $\mathbf{i}$ alt

$\begin{array}{ll}7 & 23\end{array}$

23

4

2

7

2

45

Genindlæggelser i

Sikringsanstalten

$3 \quad 13$

2

0

2

1

21

35 af de 163 patienter har foretaget en ny farlig handling efter udskrivelsen fra Sikringsanstalten. Dette giver en frekvens af farlige recidiver på $21 \%$.

Blandt de skizofrene findes farligt recidiv hos kun $10 \%$, hvilket er signifikant færre end blandt de $\varnothing$ vrige patienter $(p<0,01)$. I modsætning hertil fremviser psykopaterne en stor recidivhyp- 
pighed. 16 af disse eller $32 \%$ har efter udskrivelsen begået en ny farlig handling $(\mathrm{p}<0,02)$.

Vedrørende de $\varnothing$ vrige patientgrupper henvises til tabellen.

Det er bemærkelsesværdigt, at langt de fleste farlige recidiver er farlige aggressive handlinger i hospitalsafdelinger. Det drejer sig om 17 patienter eller ca. $50 \%$ af de farlige recidiver.

Som det ses af tabel 24 er 2 patienter registrerede for mordfors $\emptyset$.

Den ene (SA nr. 88) var en psykopat, mange gange straffet tidligere og indlagt i Sikringsanstalten for meget voldsomme trusler under ophold på Sundholm. Det farlige recidiv var et drabsforsøg med kniv mod en fængselsbetjent. På opg $\varnothing$ relsestidspunktet er patienten indlagt i psykiatrisk hospital på lukket afdeling.

Den anden (SA nr. 193) var en psykopat med seksuel perversion. Han var primært heteroseksuel, men senere udviklede han homoseksuelle praktikker ledsaget af sadistiske udtalelser om at partere kvinder og småpiger. Han indlagdes i Sikringsanstalten efter overfald på en lille pige, som han stak $i$ halsen med en kniv for at dræbe hende. Det farlige recidiv var et overfald med kvælertag på en lille pige, kort før han skulle udskrives fra psykiatrisk hospital. På opgørelsestidspunktet var patienten i psykopatforvaring.

21 patienter eller $10 \%$ af det samlede materiale har været indlagt i Sikringsanstalten mere end een gang. 13 af disse patienter var psykopater og kun 3 skizofrene. 17 har været indlagt 2 gange, 3 patienter var indlagt 3 gange ( 2 psykopater og 1 oligofren). 1 psykopat var indlagt 4 gange.

\section{b. De udskrevne patienters opholdssted:}

Tabel 25 viser, hvor de 158 patienter befandt sig på skæringsdagen eller ved deres $d \varnothing d$, for så vidt som denne indtraf efter udskrivelsen fra Sikringsanstalten.

47 patienter eller $30 \%$ af de udskrevne klarede sig udenfor institutioner, heraf 34 patienter alene (d. v. s. allerh $\varnothing$ jst med bistand af familiemedlemmer). Især klarede de udskrevne psykopater sig godt, idet 25 ( $51 \%$ ) levede ude i samfundet. Som venteligt klarede de skizofrene sig dårligere. Dog var 7 patienter (10\%) udenfor institutioner.

De fleste patienter, 89 eller $56 \%$ af de udskrevne, opholdt sig på opg $\varnothing$ relsestidspunktet eller ved $\mathrm{d} \phi \mathrm{d}$ i forskellige institutioner. 73 patienter $(46 \%)$ var således i psykiatriske hospitaler. 7 patienter $(4 \%)$ var i familiepleje, og 9 patienter $(6 \%)$ var i plejehjem. Denne gruppe domineres af de skizofrene, af hvilke 58 patienter $(87 \%)$ befandt sig i de nævnte institutioner. Dette er 
Tabel 25. 158 udskrevne patienter fordelt efter opholdssted på opg $\phi$ relsestidspunktet eller ved $\mathrm{d} \phi \mathrm{d}$.

\begin{tabular}{|c|c|c|c|c|c|c|c|}
\hline & $\begin{array}{l}\text { skizo- } \\
\text { freni }\end{array}$ & $\begin{array}{l}\text { psyko- } \\
\text { pati }\end{array}$ & $\begin{array}{l}\text { epi- } \\
\text { lepsi }\end{array}$ & $\begin{array}{l}\text { psykog. } \\
\text { psykose }\end{array}$ & $\begin{array}{l}\text { oligo- } \\
\text { freni }\end{array}$ & andet & total \\
\hline $\begin{array}{l}\text { Klarer helt sig selv } \\
\text { Klarer sig }\end{array}$ & 5 & 20 & 4 & 3 & 1 & 1 & 34 \\
\hline alene med IP & 1 & 3 & 0 & 1 & 0 & 1 & 6 \\
\hline Klarer sig med tilsyn & 1 & 2 & 2 & 2 & 0 & 0 & 7 \\
\hline Udenfor institution & 7 & 25 & 6 & 6 & 1 & 2 & 47 \\
\hline Psykiatrisk hospital & 51 & 7 & 4 & 5 & 2 & 4 & 73 \\
\hline Familiepleje & 2 & 1 & 1 & 0 & 3 & 0 & 7 \\
\hline Plejehjem & 5 & 3 & 0 & 0 & 1 & 0 & 9 \\
\hline $\begin{array}{l}\text { Psykiatrisk hospi- } \\
\text { tal m. m. }\end{array}$ & 58 & 11 & 5 & 5 & 6 & 4 & 89 \\
\hline Åndssvageanstalt & 0 & 1 & 0 & 0 & 3 & 0 & 4 \\
\hline Psykopatforvaring & 0 & 5 & 1 & 1 & 1 & 0 & 8 \\
\hline Fængsel & 0 & 2 & 0 & 0 & 0 & 0 & 2 \\
\hline Andre institutioner & 0 & 8 & 1 & 1 & 4 & 0 & 14 \\
\hline Ukendt opholdssted & 2 & 5 & 0 & 0 & 0 & 1 & 8 \\
\hline I alt udskrevne & 67 & 49 & 12 & 12 & 11 & 7 & 158 \\
\hline
\end{tabular}

signifikant flere end blandt de $\phi$ vrige patienter $(p<0,001)$. De fleste patienter, nemlig $76 \%$, var i hospitalerne. Blandt psykopaterne var derimod kun 11 patienter $(22 \%)$ i disse institutioner, hvilket er signifikant færre end blandt de $\phi$ vrige $(p<0,001)$.

I andre institutioner befandt sig 14 patienter (9\%). Heraf var 8 patienter i psykopatforvaring, 4 i åndssvageanstalt, medens kun 2 patienter var i fængsel. Blandt patienterne i denne gruppe var der forståeligt nok ingen skizofrene, men 8 var psykopater.

8 patienter er det ikke lykkedes at opspore. Af disse var 5 psykopater.

c. De på opgфrelsestidspunktet d $\phi$ de patienter:

Som det ses af tabel 26 er der blandt Sikringsanstaltens patienter mange, der er d $\varnothing$ de på opgørelsestidspunktet.

Det drejer sig om i alt 57 patienter $(28 \%)$. Blandt de skizofrene patienter og psykopaterne er fordelingen mellem levende og d $\varnothing$ de som i totalmaterialet, hvilket ikke overrasker, da disse grupper jo på grund af deres størrelse i h $\varnothing \mathbf{j}$ grad præger mate- 
Tabel 26. Fordelingen mellem levende og d $\varnothing$ de på opg $\varnothing$ relsestidspunktet i relation til diagnoser, herunder fordelingen mellem d $\varnothing$ de i Sikringsanstalten og efter udskrivelse herfra.

\begin{tabular}{|c|c|c|c|c|c|c|c|}
\hline & $\begin{array}{l}\text { skizo- } \\
\text { freni }\end{array}$ & $\begin{array}{c}\text { psyko- } \\
\text { pati }\end{array}$ & $\begin{array}{c}\text { epi- } \\
\text { lepsi }\end{array}$ & $\begin{array}{l}\text { psykog. } \\
\text { psykose }\end{array}$ & $\begin{array}{l}\text { oligo- } \\
\text { freni }\end{array}$ & andet & tstal \\
\hline \multirow{2}{*}{$\begin{array}{l}\text { D } \varnothing \text { de i SA } \\
\text { Døde efter ud- } \\
\text { skrivning }\end{array}$} & 13 & 4 & 5 & 0 & 0 & 3 & 25 \\
\hline & 10 & 10 & 6 & 1 & 3 & 2 & 32 \\
\hline $\mathrm{D} \phi$ de i alt & 23 & 14 & 11 & 1 & 3 & 5 & 57 \\
\hline Levende & 68 & 44 & 8 & 11 & 8 & 7 & 146 \\
\hline Total & 91 & 58 & 19 & 12 & 11 & 12 & 203 \\
\hline
\end{tabular}

rialet. Til gengæld ses, at blandt de skizofrene er flest d $\phi$ de i Sikringsanstalten, medens der blandt psykopaterne kun er fâ, der er døde under deres ophold dér. Denne forskel er dog ikke statistisk signifikant.

Særlig påfaldende er det store antal døde blandt epileptikerne, såvel i Sikringsanstalten som efter udskrivelsen. Det drejer sig om 11 af i alt 19 patienter (58\%). Sammenlignet med resten af materialet er denne forskel statistisk signifikant $(p<0,01)$.

25 patienter er d $\varnothing$ de under deres ophold i Sikringsanstalten. 3 af disse suiciderede, alle ved hængning. 2 af patienterne var skizofrene og 1 var psykopat.

32 patienter er d $\varnothing$ de efter deres ophold i Sikringsanstalten. 4 af disse patienter suiciderede, een ved indtagelse af nikotin, de $\phi$ vrige uoplyste. Det drejer sig om 2 psykopater, 1 skizofren og 1 epileptiker.

I alt er der således 7 suicidier, hvoraf 3 var i Sikringsanstalten.

I $\varnothing$ vrigt er det oplyst, at 2 epileptikere d $\varnothing$ de ved drukning under badning (epileptisk anfald?).

\section{d. Psykofarmaka:}

Blandt de udskrevne skizofrene patienter er 23 blevet behandlet med de moderne psykofarmaka, medens 21 ,kun“ har fået ældre stoffer. Disse 2 grupper er små, og yderligere er den farmakologiske indsats kun én side af behandlingen, hvorfor en sammenligning er vanskelig.

I tabel 27 er opf $\varnothing \mathrm{rt}$ nogle kvaliteter til sammenligning mellem de 2 grupper, men i ingen af tilfældene er forskellen statistisk signifikant. Mest udtalt er en tendens til kortere behandlingstid blandt de psykofarmaka-behandlele patienter $(0,10>p>0,05)$. Det ses, at der ikke var farlige recidiver blandt de psykofarmakabehandlede skizofrene. 
Tabel 27. 44 udskrevne medikamentelt behandlede skizofrene patienter, af hvilke 23 har fået moderne psykofarmaka, og 21 „kun“ har fået ældre medikamenter. Sammenligning med hensyn til udvalgte kriterier.

\begin{tabular}{lrrr}
\hline & $\begin{array}{c}\text { psyko- } \\
\text { farm. }\end{array}$ & $\begin{array}{c}\text { ældre } \\
\text { medic. }\end{array}$ & total \\
\hline Indlagt for grov vold, mord og mordfors $\varnothing$ g & 11 & 6 & 17 \\
Behandlingstid under 5 år & 12 & 5 & 17 \\
På skæringsdagen i psyk. inst. & 21 & 17 & 38 \\
Farligt recidiv & 0 & 2 & 2
\end{tabular}

\section{Efterforlфbets diagnoser:}

De på tidspunktet for den farlige handling gældende diagnoser har på opg $\phi$ relsestidspunktet stort set kunnet bekræftes. Dog er yderligere 6 patienter blevet sikkert skizofrene. Af disse rubriceredes 3 oprindeligt som psykogene psykoser, 2 som psykopati og 1 som epilepsi.

Sammenfatning af resultaterne.

A. Opgфrelse:

1. $45 \%$ af patienterne var skizofrene, $29 \%$ psykopater. Ingen af de $\phi$ vrige grupper udgjorde over $10 \%$.

2. Ved tværsnitsunders $\varnothing$ gelser fra 1938, 1946, 1953, 1956, 1957 og 1962 påvises, at skizofrenien er endnu mere dominerende og psykopatien betydeligt mindre repræsenteret i tværsnittene end i hele materialet.

3. Korrigeres der for patientkategorier, som ikke modtages $\mathbf{i}$ Sikringsanstalten, finder man samme procentdel skizofrene i Sikringsanstalten som i det reducerede baggrundsmateriale for 1957. I 1962 var der derimod $11 \%$ færre skizofrene i Sikringsanstalten end $\mathrm{i}$ det tilsvarende reducerede baggrundsmateriale.

4. For samtlige diagnoser var 4,2 promille og 3,7 promille af baggrundsmaterialet indiagt i Sikringsanstalten i hhv. $1957 \mathrm{og}$ 1962. Af det reducerede baggrundsmateriale er andelene hhv. 5,5 promille og 5,3 promille, altså ingen væsentlig forskel. Tallene for skizofreni er derimod hhv. 5,4 promille og 4,4 promille.

5. De farlige handlinger var hos halvdelen af patienterne grove voldshandlinger af farlig karakter. Denne gruppe er den største blandt de skizofrene.

For godt $1 / 5$ drejede det sig om mord og mordfors $\varnothing$ g. Denne gruppe er psykopaternes største. 
For $1 / 7$ af materialet drejede det sig om brandstiftelse. De fleste af patienterne var her psykopater.

6. $142(70 \%)$ var ufaglærte arbejdere, $25(12 \%)$ var faglærte. 18 patienter $(9 \%)$ havde intet erhverv. 8 var i liberale erhverv, 5 i funktionærstillinger og 5 var akademikere. Der var ingen forskel på de diagnostiske grupper.

$15 \%$ var f $\varnothing \mathrm{dt}$ udenfor ægteskab, $19 \%$ havde som børn været i institutioner. Dårlige forhold $\mathrm{i}$ barndommen fandtes yderligere hos $37 \% .13 \%$ var asociale og $33 \%$ ustabile arbejdere.

Hos $\mathrm{i}$ alt 146 patienter $(72 \%)$ registreredes dårlige sociale forhold under en eller anden form, medens 57 (28\%) ikke frembød sådanne dårlige forhold. Den socialt dårlige gruppe indeholder signifikant færre skizofrene og flere psykopater end gruppen uden dårlige sociale forhold. Der er ingen sikker forskel med hensyn til de farlige handlingers art $\mathrm{i}$ de to grupper.

7. De hyppigst registrerede præmorbide karaktertræk er holdningsl $\phi$ shed ( 56 patienter), eretisme (39 patienter), affektlabilitet (32 patienter) og selvhævdelse (31 patienter).

Oplysninger om præmorbide træk findes hos 161 patienter $(79 \%)$, men mangler for $42(21 \%)$. Blandt disse fordeler de skizofrene sig med hhv. 61 og 30 patienter i hver gruppe, således at de skizofrene er dårligere belyst på dette punkt end resten. Blandt psykopaterne findes 56 patienter med og 2 patienter uden oplysninger om præmorbide karaktertræk, hvorved de er bedre belyst end de $\phi$ vrige.

Kun 35 patienter $(17 \%)$ var spiritusmisbrugere. Heraf var 15 psykopater og 10 skizofrene.

8. $53 \%$ af samtlige patienter blev syge før det 20 . år, $82 \%$ f $\phi \mathrm{r}$ det 30 . år. Kun $4 \%$ blev syge ved 40 års alderen eller senere.

20 skizofrene $(22 \%)$ blev syge f $\phi \mathrm{r}$ det 20 . år og yderligere $45(49 \%)$ inden 30 års alderen. Derimod opstod ingen skizofreni efter det 50. år.

9. 156 patienter ( $77 \%$ ) havde været kriminelle f $\phi \mathbf{r}$ den farlige handling, der f $\phi$ rte til anbringelse i Sikringsanstalten, 47 patienter $(23 \%)$ derimod ikke. Gruppen, hvis første lovovertrædelse ikke var den farlige handling, domineres af psykopaterne, gruppen, hvor den farlige handling var den første lovovertrædelse, af de skizofrene.

Blandt de skizofrene, der har været kriminelle f $\varnothing \mathrm{r}$ den farlige handling, har ca. $40 \%$ været kriminelle f $\phi \mathrm{r}$ det 20 . år, hvilket er færre end blandt resten af patienterne. Blandt de psykopater, der har været kriminelle $\mathrm{f} \phi \mathrm{r}$ den farlige handling, har ca. $80 \%$ været kriminelle f $\phi \mathrm{r}$ det 20 . år, hvilket er flere end blandt resten.

10. $90 \%$ af alle patienter var $20-50$ år ved den farlige handling. 1 patient var over 60 år. Medens der blandt psykopaterne 
var overvægt af patienter under 30 år ved den farlige handlings foretagelse, var de fleste skizofrene over 30 år på dette tidspunkt.

11. Blandt 134 patienter (ekscl. psykopater og oligofrene) havde 97 (72\%) været syge i mere end 5 år, og yderligere 25 patienter havde været syge $\mathrm{i}$ over 1 år ved den farlige handlings udf $\varnothing$ relse. Der er signifikant flere tilfælde af grove voldshandlinger blandt skizofrene med over 5 års sygdomsvarighed end blandt de skizofrene med kortere sygdomsvarighed.

12. $115(57 \%)$ har $\mathrm{f} \phi \mathrm{r}$ den farlige handling tidligere været indlagt i psykiatrisk hospital. Både blandt de skizofrene og epileptikerne er der flest med og blandt psykopaterne flest uden tidligere indlæggelse. Der er flere tilfælde af grove voldshandlinger blandt patienterne med tidligere indlæggelse, men flere tilfælde af mord og mordfors $\phi \mathrm{g}$, brandstiftelse og voldtægtsforbrydelser hos patienter uden forudgånde indlæggelse.

13. De på tidspunktet for den farlige handling særligt fremtrædende symptomer var paranoide forestillinger hos $31 \%$, hallucinationer på syn og/eller hørelse hos $24 \%$. Oplysninger om sådanne symptomer kan kun gives for 114 patienter $(56 \%)$, heraf 76 skizofrene. Derimod mangler sådanne oplysninger oftest blandt psykopater, epileptikere og oligofrene.

14. Blandt de 76 skizofrene patienter med oplysninger om fremtrædende symptomer på tidspunktet for den farlige handling findes paranoide forestillinger og hallucinationer hos $\mathrm{i}$ alt 68 patienter. 55 af de 76 patienter har for $\phi v e t$ grove voldshandlinger af farlig karakter. Der kan dog ikke påvises nogen statistisk sammenhæng mellem paranoide forestillinger og hallucinationer på den ene side og grove voldshandlinger på den anden side hos skizofrene patienter.

15. 123 patienter $(61 \%)$ er administrativt anbragt, og 80 patienter $(39 \%)$ er anbragt ved dom. Det er især de skizofrene, der er anbragt administrativt (74\%). Psykopaterne er overvejende anbragt ved dom (59\%). Det er især de ældre patientgrupper, der overvejende er administrativt anbragte, medens de yngste grupper i højere grad er domsanbragte.

Grove voldshandlinger er især for $\phi$ vet af de administrativt anbragte, medens mord og mordfors $\varnothing \mathrm{g}$ især er for $\varnothing$ vet af de domsanbragte. Med hensyn til tidligere kriminalitet er der ingen forskel på de domsanbragte og de administrativt anbragte patienter.

16. $64 \%$ af patienterne har været i beskæftigelsesterapi. Dette gælder kun $45 \%$ af de skizofrene, men $81 \%$ psykopater.

Medikamina af ældre art $\mathbf{i}$ form af sedativa og hypnotika har været anvendt til 108 patienter (53\%), men relativt sjældent til de skizofrene. De nye psykofarmaka (serpasil, fentiaziner etc.) er nu anvendt til 51 patienter $(25 \%)$, hvoraf 34 patienter er 
skizofrene. Krampebehandling (oftest ETC) er anvendt til 18 patienter, heraf 15 skizofrene. Lobotomi er anvendt til 14, heraf 12 skizofrene. 4 patienter er blevet kastreret.

17. 158 patienter $(78 \%)$ er udskrevet fra Sikringsanstalten på skæringsdagen. 25 var døde i Sikringsanstalten, 20 var indlagte på skæringsdagen. Blandt de udskrevne var $7 \%$ indlagt i under 1 år og lige så mange $\mathrm{i}$ over 20 år. Ca. halvdelen havde ophold på $1-5$ år og ca. $1 / 3$ på $6-20$ år.

De skizofrene var indlagt særlig længe, psykopaterne havde derimod relativt korte ophold. Der er ingen sikker forskel på opholdstiden i Sikringsanstalten i ældre og nyere tid.

\section{B. Efterundersфgelsen:}

1. Blandt de 158 udskrevne patienter er observationstiden for $14(9 \%)$ mindre end 3 år. 114 patienter $(72 \%)$ har en observationstid på over 5 år, 76 patienter $(48 \%)$ en observationstid på over 10 år. Der er ingen diagnostiske forskelle i denne henseende.

2. Blandt 163 patienter med mulighed for kriminelt og farligt recidiv har 35 patienter $(21 \%)$ haft recidiv til farlige handlinger. Blandt de skizofrene findes farligt recidiv hos 7 patienter $(10 \%)$. Blandt psykopaterne var der farligt recidiv hos 16 patienter $(32 \%)$.

Halvdelen af de farlige recidiver var farlige aggressive handlinger i hospitalsafdelinger. 2 patienter gjorde sig skyldige i mordfors $\varnothing \mathrm{g}$.

3. 21 patienter eller $10 \%$ af det samlede materiale havde været indlagt mere end een gang i Sikringsanstalten. 13 af disse var psykopater, 3 skizofrene. I alt 17 patienter havde været indlagt 2 gange, 3 patienter 3 gange og 1 patient 4 gange.

4. Af de udskrevne klarede 47 patienter (30\%) sig udenfor institutioner, de $34(22 \%)$ endda helt selv. 25 var psykopater og 7 skizofrene. Af 89 patienter $(56 \%)$ i forskellige institutioner var $73(46 \%)$ i psykiatriske hospitaler, $7(4 \%)$ i familiepleje og $9(6 \%)$ i plejehjem. 58 var skizofrene, hvoraf 51 var i hospitalerne. 11 var psykopater.

8 patienter var i psykopatforvaring, 4 var i åndssvageanstalt, 2 i fængsel. 8 patienter er det ikke lykkedes at opspore.

5. 57 patienter $(28 \%)$ var døde på opg $\varnothing$ relsestidspunktet. Der er en statistisk signifikant overd $\varnothing$ delighed blandt epileptikerne. 25 patienter d $\varnothing$ de i Sikringsanstalten, 32 efter udskrivelsen herfra. Der var 7 suicidier, heraf 3 i Sikringsanstalten (alle ved hængning), og 4 efter udskrivelsen. 
6. Ved sammenligning af psykofarmakabehandlede udskrevne skizofrene med udskrevne skizofrene behandlede med ældre medikamina findes ingen signifikante forskelle med hensyn til udvalgte kriterier. Dog antydes, at de psykofarmakabehandlede i forhold til de andre har haft kortere behandlingstid.

7. Medens antallet af indlagte patienter i Sikringsanstalten tidligere har ligget nogenlunde konstant omkring maksimumstallet 50 patienter, er antallet siden midten af halvtredserne jævnt dalet til 17 patienter i 1963. Faldet $\mathrm{i}$ antallet af indlagte patienter falder sammen med anvendelsen af psykofarmaka i den psykiatriske terapi.

8. Efterforl $\phi$ bet har vist, at yderligere 6 patienter efter den farlige handling blev skizofrene. Af disse var oprindeligt $3 \mathrm{ru}-$ briceret som psykogene psykoser, 2 som psykopatier og 1 som epilepsi. Der er ikke korrigeret herfor i opg $\phi r e l s e n$.

\section{Diskussion og konklusion.}

Bed $\varnothing$ mmelsen af et materiale som det her fremlagte byder på adskillige vanskeligheder. Patienterne er udvalgte over en periode på næsten 50 år. Herved har man opnået at få alle med og dermed et materiale af rimelig størrelse. Derimod er det ikke muligt at finde et materiale, der er egnet til sammenligning med vort. Endvidere har man ved den anvendte metode været henvist til aktstykker incl. journaler, hvor mangelen af visse relevante oplysninger om patienterne næppe altid har betydet disses manglende forekomst, men eventuelt blot manglende registrering.

Materialet er udvalgt, idet alle patienter anses for både sindssyge og overordentlig farlige ved indlæggelsen i Sikringsanstalten. Med de fremlagte data som grundlag kan derfor ikke drages konklusioner vedrørende de enkelte psykiatriske lidelser i almindelighed; de belyser udelukkende patientmaterialet, behandlingsmulighederne og resultatet heraf $i$ et terapeutisk milj $\phi$, der også har fængselsmæssigt sigte.

I det følgende skal ber $\varnothing$ res enkelte hovedpunkter, specielt vedrørende forskelle mellem skizofrene og psykopater.

Gennem mange år har den opfattelse været fremherskende, at især skizofreni disponerer til svære forbrydelser (Birnbaum, 1931; Wetzel, 1932; Glaser, 1934; Lange, 1934; Schipkowensky, 1938, 1957; Wilmanns, 1940; Schottky, 1941; Kaila, 1942, 1957; Tomorug, 1957).

Skizofreni er den i Sikringsanstalten hyppigst forekommende sygdom. Dette synes dog ikke at skyldes, at denne patientgruppe er farligere end de $\phi$ vrige diagnostiske grupper, men blot at sygdommen i sig selv er relativt hyppig i hospitalsmiljø. I vort materiale tyder tallene fra de senere års tværsnit netop på, at de 
skizofrene ikke er farligere end de $\phi$ vrige patientkategorier. Der er ikke procentvis flere skizofrene i Sikringsanstalten end i baggrundsmaterialet i 1957. De synes endda i aftagende grad farlige eller lettere at behandle end tidligere udenfor Sikringsanstalten, idet tallene fra 1962 viser procentvis færre i Sikringsanstalten end i baggrundsmaterialet, et udtryk for betydelig nedgang i antallet af skizofrene i Sikringsanstalten, da netop disse patienter også er blevet færre i baggrundsmaterialet i nævnte tidsrum (Juel-Nielsen \& Strömgren, 1963). De absolutte tal fra Sikringsanstalten er dog meget små og tillader ikke vidtgående konklusioner, men at antallet af meget farlige skizofrene er lille (Bürger-Prinz, 1941; Macniven, 1944; Brack-Kletzhändler, 1954; Wanner, 1954; Johanson, 1958; Mayer-Gross et al., 1960) bekræftes af, at der kun findes 5,4 promille og 4,4 promille af baggrundsmaterialets skizofrene mænd i Sikringsanstalten i hhv. 1957 og 1962. Dette svarer til, at een patient af hver $200-250$ hospitaliserede skizofrene mænd befinder sig i Sikringsanstalten. Regner man med lige mange skizofrene mænd og kvinder og antager, at der er 3 promille skizofrene $\mathrm{i}$ befolkningen (Strömgren, 1964) fås, at der er een patient i Sikringsanstalten ud af hver ca. 500 skizofrene mænd i Danmark.

Imidlertid er de skizofrene stadig den gruppe, der er vanskeligst helt at resocialisere, selv om de med moderne psykofarmaka er lettere at pacificere. De er endnu mere dominerende i tværsnittene end totalmaterialet, og er altså vanskeligere at få udskrevet fra Sikringsanstalten end andre patientgrupper, men dette svarer ganske til patienterne på psykiatriske hospitaler i $\varnothing$ vrigt (Juel-Nielsen \& Strömgren, 1963).

I modsætning hertil har psykopaterne gennemgående haft relativt korte indlæggelser. De har imidlertid især tidligere været meget belastende ved deres antal og egenart. I de f $\phi$ rste 2 decennier var der således næsten lige mange psykopater og skizofrene, hvilket vanskeliggjorde terapien af de egentlig sindssyge patienter (Lemmergård \& Ravn, 1938). Sk $\varnothing$ nt man ikke har fors $\varnothing$ gt en opdeling af psykopaterne i diagnostiske undergrupper, er det karakteristisk, at de væsentlige præmorbide træk er holdningsl $\varnothing$ shed, eretisme, affektlabilitet og selvhævdelse, oftest i kombination. Disse træk omfatter 48 af de 58 psykopater. Hvis man erstatter ordet eretisme med eksplosivitet (Wimmer, 1936), svarer disse kategorier til 4 af Schneiders typer. Blandt disse angives forbrydelser som svære voldshandlinger, drab og voldtægt især at forekomme (Helweg, 1949), hvilket også gælder for patienterne i dette materiale.

Farligheden bestod hos de fleste af Sikringsanstaltens patienter - halvdelen af materialet - i grove voldshandlinger. $2 / 3$ af de skizofrene er af denne kategori, hvilket bekræfter den anta- 
gelse, at voldshandlinger er de skizofrenes typiske lovovertrædelse (Helweg, 1949, 1951; Langfeldt, 1959). At den især tidligere vanskelige behandlingssituation har gjort sig gældende ses i $\phi \mathrm{v}$ rigt af, at mange af disse skizofrene er indlagt i Sikringsanstalten direkte fra andre psykiatriske hospitaler som følge af den dér udviste adfærd, et forhold der også tidligere har været fremhævet (Otto Jacobsen, 1947).

Ca. $1 / 4$ af materialets psykopater har foretaget grove voldshandlinger i overensstemmelse med deres egenart som ovenfor nævnt, og i $\varnothing$ vrigt dominerer blandt disse patienter mord og mordfors $\varnothing g$, brandstiftelse og voldtægt.

Vedrørende spørgsmålet om der er sammenhæng mellem sygdommens forl $\varnothing \mathrm{b}$ og den farlige handling, gælder det for de skizofrene, at de har været syge længe og oftest tidligere har været indlagt i psykiatriske afdelinger. De har fortrinsvis begået grove voldshandlinger. Herunder har de ikke haft symptomer, der kunne antages særlig affine til netop disse handlinger. De dominerende symptomer var tværtimod karakteristiske for hovedparten af de skizofrene, uanset den farlige handlings art.

Hvornår psykopaterne har manifesteret deres karakterdefekter kunne ikke påvises. Dertil var oplysningerne for usikre. Disse patienter har sjældnere været indlagt i psykiatriske afdelinger tidligere og synes overvejende at begå andre handlinger, hvilket formentlig skyldes, at de i modsætning til de skizofrene har haft større frihed dertil. Om symptomer ved den farlige handling har man for psykopaternes vedkommende ikke tilstrækkeligt kendskab.

Den i Sikringsanstalten givne behandling har været af samme art som i andre psykiatriske institutioner, og nye fremskridt har fundet indpas i takt med udviklingen andre steder. De skizofrene patienter har været vanskeligst at beskæftige, ligesom medikamentel behandling i begyndelsen ikke altid var gennemf $\phi$ rlig. Nyere behandlingsmetoder som ECT og lobotomi er da også især anvendt til de skizofrene patienter, men først psykofarmakas indf $\varnothing$ relse betyder en landvinding, der har sat sig spor i Sikringsanstaltens belægning.

Medens tidligere et fåtal af patienter blev udskrevet direkte til friheden (Lemmergård \& Ravn, 1938; Otto Jacobsen, 1947), har dette ikke været tilfældet siden 1953, idet alle patienter nu udskrives til anden psykiatrisk institution.

Hvad angår såvel de sociale muligheder som recidiv-tilb $\varnothing$ jeligheder er der karakteristiske forskelle mellem skizofrene og psykopater, men forskelle der tvangfrit lader sig forklare ved selve sygdommens væsen. Ca. $90 \%$ af de udskrevne skizofrene opholder sig således $\mathrm{i}$ institutioner, medens godt halvdelen af psykopaterne klarer sig udenfor. De farlige recidiver forekommer over- 
vejende hos psykopaterne, men er få hos de skizofrene. Andre forskelle af betydning er, at de skizofrene oftere er administrativt anbragte i Sikringsanstalten, ligger der længere og sjældnere genindlægges, medens psykopaterne oftest er anbragt ved dom, har relativt korte ophold og hyppigere er blevet genindlagt i Sikringsanstalten.

Ingen af de farlige recidiver havde $\phi \phi d e n$ til følge. At halvdelen af alle farlige recidiver har fundet sted i hospitalsmiljø understreger det betydningsfulde $i$, at alle patienter, der udskrives fra Sikringsanstalten, i f $\phi$ rste omgang overflyttes til anden psykiatrisk institution. At nogle patienter atter er blevet farligt aggressive efter igennem meget lang tid at have vist rolig og veltilpasset adfærd i Sikringsanstalten, viser til gengæld, hvor vanskelig vurderingen af recidivsandsynligheden er.

De ufarlige recidiver skal ikke kommenteres yderligere. De lave tal hænger selvsagt sammen med den anvendte metodik, der kun har kunnet medtage, hvad der i forvejen er registreret hos bl. a. rigsregistraturen.

Sikringsanstalten har i tidens $1 \varnothing \mathrm{b}$ været genstand for gennemgribende ændringer såvel vedrørende belægningens sammensætning som patienternes antal. I perioden op til omkring 1938 var der adskillige oligofrene patienter og især mange psykopater (Lemmergård \& Ravn, 1938). Senere har der overhovedet ikke været patienter med hoveddiagnosen oligofreni, hvilket skyldes åbningen af Rødbygård i 1930. Ligeledes er antallet af psykopater faldet noget takket være åbningen af forvaringsanstalten i Herstedvester i 1935. Medens Sikringsanstalten i betydeligt omfang aflastede hospitalerne og i nogen grad også forvaringsanstalten (Otto Jacobsen, 1947), mærkedes en tydelig begyndende ændring fra midten af halvtredserne med både færre indstillinger og flere udskrivninger end tidligere (Kirkegaard, 1956), og en yderligere nedgang i patientantallet blev forudset. På skæringsdagen for vor unders $\varnothing$ gelse, 1.5.1962, var kun 20 patienter i Sikringsanstalten, og antallet er senere yderligere reduceret, så det i 1965 var nede på 13 patienter. Årsagerne hertil er dels de moderne behandlingsmetoder og intensivering af ældre, dels gennemgribende moderniseringer såvel vedrørende lokaliteter som personale.

\section{Efterskrift:}

Gennem årene har flere af Sikringsanstaltens patienter været genstand for omtale i litteraturen. Således har Tage-Jensen (1942) under omtale af danske kriminalsager fra perioden 1838-1938 omtalt patienterne nr. 23, 54 og 155. Arnfred (1944) har omtalt patient nr. 146 på et tidspunkt, hvor denne endnu ikke havde været indlagt i Sikringsanstalten. Arnfred (1946) har endvidere udførligt beskrevet sygehisto- 
rien for patient $\mathrm{nr}$. 112. Helweg (1949) har omtalt patient $\mathrm{nr}$. 155, og Clemmesen (1957) har behandlet spørgsmålet om karakterogen paranoia $\mathrm{i}$ en kasuistik om patient nr. 108. Endelig har Jacobsen \& Schourup (1965) offentliggjort sygehistorien for patient $\mathrm{nr}$. 54 .

\section{Resumé.}

Sikringsanstalten er en institution for farlige sindssyge mænd, der kan indlægges efter justitsministeriel resolution eller domstolsafg $\phi$ relse. Den blev oprettet i henhold til særlig lov fra 1913 og taget i brug i 1918.

Den 1. maj 1962 havde der været indlagt 203 patienter. 80 var d $\varnothing \mathrm{mt}$ til anbringelse, 123 anbragt administrativt. Knapt halvdelen $(45 \%)$ var skizofrene, $29 \%$ var psykopater. Ingen af de $\phi$ vrige grupper udgjorde over $10 \%$. Antallet af patienter har ligget ret konstant indtil 1950'ernes midte, hvorefter det er dalet jævnt. Antallet af skizofrene patienter er dalet mere end i baggrundsmaterialet.

Indlæggelsesårsagen var i ca. $50 \%$ grove voldshandlinger, i ca. $20 \%$ mord og mordfors $\varnothing \mathrm{g}$, i $14 \%$ brandstiftelse. Blandt de skizofrene findes især grove voldshandlinger, blandt psykopaterne er mord og mordfors $\phi \mathrm{g}$ lige så hyppige som grove voldshandlinger. I $\phi$ vrigt forekom voldtægt og grove trusler.

Ca. $75 \%$ havde været kriminelle f $\phi \mathbf{r}$ den farlige handling, flest blandt psykopaterne, færrest blandt de skizofrene. Ved den farlige handling var psykopaterne væsentlig yngre end de skizofrene.

$70 \%$ var ufaglærte arbejdere. $15 \%$ var f $\not \mathrm{dt}$ udenfor ægteskab og $19 \%$ havde tidligere været anbragt i forskellige institutioner. $37 \%$ havde dårlige forhold $\mathrm{i}$ barndommen. $13 \%$ var asociale. Psykopaterne var socialt dårligere stillet end de skizofrene.

En sammenhæn mellem sygdomsforl $\phi$ bet og den farlige handlings art kan kun påvises blandt skizofrene, hvor der er større frekvens af grove voldshandlinger blandt patienter med mere end 5 års sygdomsvarighed end blandt patienter med kortere sygdomsvarighed.

De fleste skizofrene har været hospitaliseret $f \phi r$ den farlige handling, hvilket kun gælder for få psykopater.

Man kan ikke statistisk påvise en sammenhæng mellem fremtrædende symptomer i gernings $\varnothing$ jeblikket og den farlige handlings art.

Terapien var i overensstemmelse med de principper, der på de forskellige tidspunkter var fremherskende på vore psykiatriske institutioner i $\varnothing$ vrigt, og som kunne tilpasses dette specielle klientel og de specielle omgivelser.

På skæringsdagen var udskrevet 158 patienter. Heraf klarede $30 \%$ sig udenfor institutioner, heriblandt 25 psykopater og 7 
skizofrene. $56 \%$ fandtes i psykiatriske hospitaler (46\%), plejehjem $(6 \%)$ og familiepleje $(4 \%)$. Blandt disse var 58 patienter skizofrene og 11 psykopater.

Recidiver til farlige handlinger fandtes hos i alt $21 \%$ af dem, der havde haft mulighed derfor, blandt psykopaterne hos $32 \%$, blandt de skizofrene hos $10 \% .21$ patienter var indlagt mere end 1 gang i Sikringsanstalten. Af disse var 13 psykopater og 3 skizofrene.

\section{LITTERATUR}

1. Arnfred, A. H.: Et tilfælde af drab i akut psykose. Nordisk Tidsskrift for strafferet. 1944: 32: 156-182.

2. Arnfred, A. H.: A case of matricide the perpetrator of which subsequently proved to be a schizophrenic. Acta psychiat. scand. 1946: 21: $21-38$.

3. Arentsen, K. \& E. Strömgren: Patients in Danish psychiatric hospitals. Results of a census in 1957. Acta Jutlandica XXXI, 1, Medical Series 9. Munksgaard, Copenhagen 1959.

4. Birnbaum, K.: Kriminalpsychopathologie und psychobiologische Verbrecherkunde. 1931.

5. Brack-Kletzhändler, E.: Zum Problem der Kriminalität der Schizophrenen. Mschr. Psychiat. Neurol. 1954: 128: 129-152.

6. Bürger-Prinz, H.: Schizophrenie und Mord. Mschr. Kriminalbiol. 1941: 32: 149-161.

7. Clemmesen, G.: Om fejlbehandling af karakterogen paranoia. Ugeskr. Læg. 1957: 119, 1562-1568.

8. Glaser, J.: Tötungsdelikt als Symptom von beginnender oder schleichend verlaufender Schizophrenie. Z. ges. Neurol. Psychiat. 1934: 150: 1-41.

9. Helweg, H.: Den retslige psykiatri i kort omrids. H. Hagerup, K $\varnothing$ benhavn 1949.

10. Helweg, H.: Motivdannelse ved lovovertrædelser. Ugeskr. Læg. 1951: 113, 1177-1183.

11. Jacobsen, O.: Treatment of criminal psychopaths in the Detention Institution and Mental Hospital at Nyk $\varnothing$ bing Seeland, Denmark. Acta psychiat. scand., suppl. 1947: 47: 42-53.

12. Jacobsen, O. \& K. Schourup: En psykiatrisk kasuistik. Findes i: SNS gennem 50 år, K $\phi$ benhavn 1965.

13. Johanson, E.: A Study of Schizophrenia in the Male. Acta psychiat. scand. 1958: suppl. 125.

14. Juel-Nielsen, N. \& E. Strömgren: Five Years Later. Acta Jutlandica XXXV, 1, Medical Series 13, København 1963.

15. Kaila, M.: Schizofreni och Kriminalitet. De nordiska Kriminalistföreningarnas Årsbok 1940—41, p. 17—22. Malmø 1942. 
16. Kaila, M.: Schizophrenie und Kriminalität. Congress Report, Vol. IV, p. 405-407. II. int. Kongress für Psychiatrie, Zürich 1957.

17. Kemp, T.: Statistik for medicinere. København 1955.

18. Kirkegaard, Aa.: De moderne behandlingsmetoder i psykiatrien og sikringsanstaltens fremtid. Nordisk Tidsskrift for Kriminalvidenskab 1956, 44: 243-250.

19. Lange, J.: Spezielle gerichtliche Psychopathologie. Findes i: A. Hoche (ed.): Handbuch d. gerichtl. Psychiatrie, Berlin 1934.

20. Langfeldt, G.: Rettspsykiatri for jurister og læger. 2. udg. Oslo 1959.

21. Lemmergaard, $K$. \& J. Ravn: Patientbelægningen på sikringsanstalten i Nykøbing med særligt henblik på psykopatierne. Nordisk medicinsk Tidsskrift 1938: 16: 1898-1902.

22. Macniven, A.: Psychoses and Criminal Responsibility. Findes i: Radzinowicz \& Turner (ed.) : Mental Abnormality and Crime. London 1944.

23. Mayer-Gross, W., E. Slater \& M. Roth: Clinical Psychiatry, London 1960.

24. Schipkowensky, N.: Schizophrenie und Mord. Berlin 1938.

25. Schipkowensky, N.: Schizophrenie und Mord. II. int. Kongress für Psychiatrie. Congress Report vol. IV, p. 433-443.

26. Schottky, J.: Ueber Brandstiftungen von Schizophrenen. Z. Neur. 1941: 173, 109-177.

27. Strömgren, E.: Psykiatri, 8. udg. 1964.

28. Tage-Jensen, S.: Danske Kriminalsager 1838-1938. Forlaget Norden, Odense 1942.

29. Tomorug, E.: Schizophrenie und Kriminalität. Congress Report vol. IV, p. 407-416. II. int. Kongress f. Psychiatrie. Zürich 1957.

30. Wanner, O.: Schizophrenie und Kriminalität. Mschr. Kriminol. Strafrechtsref. 1954: $3 \%, 1-33$.

31. Wetzel, A.: Die soziale Bedeutung (d. Schiz.). Findes i: O. Bumke (ed.) : Handb. d. Geisteskrankheiten, Band IX. Berlin 1932.

32. Wilmanns, $K$.: Ueber Morde im Prodromalstadium der Schizophrenie. Z. Neur. 1940: 170: 583-662.

33. Wimmer, A.: Speciel klinisk psykiatri. København 1936. 